\title{
Medya İçeriğinde Şiddetin Sunumu Üzerine Argümantatif Bir Çalışma
}

\section{Nur ERDEM ${ }^{1}$}

Öz

Gerek geleneksel, gerekse dijital medyada şiddet, neredeyse gündelik hayatın bir parçası haline gelmiş sıradan bir olgu olarak karşımıza çıkmaktadır. Dolayısıyla, ne medyada şiddetin varlığı, ne de bu konu üzerinden yürütülen tartışmalar yenidir. Öte yandan şiddetin kurgusal içerikteki sunumu farklı bir bakış açısıyla ele alınmalıdır, özellikle de estetize edilmesi bağlamında. Şiddet ve saldırganlığın insan doğasının bir parçası olup olmadığı ve / veya bireyi şiddet uygulamaya, saldırgan tutum ve davranışlar sergilemeye iten nedenler üzerine yapılan tartışmalar bir yana, var olan gerçekliklerden biri de bireyin gün içerisinde sıklıkla şiddet içerikli medya mesajlarına maruz kaldığıdır. Bu mesajlar çoğu kez estetize edilmiş bir biçimde sunulmakta, izleyici tarafindan da pornografik olarak yorumlanmaktadır. Bu noktada izleyici ne kendini şiddet yüklü içerikleri izlemekten alıkoyabilmekte, ne de eleştirel bakmaktan kaçabilmektedir. $\mathrm{Bu}$ çalışmada, medya içeriğinde şiddetin sunumu üzerine kuramsal bir tartışma gerçekleştirilmektedir. İlk olarak, şiddet kavramı etimolojik boyutuyla ele alınmakta, hemen ardından insan doğasında şiddet ve saldırganlığın neden ve nasıl var olduğunu sorgulayan yaklaşımlar değerlendirilmektedir. Akabinde, çalışmanın odak noktasını oluşturan, medya içeriğinde şiddetin pornografik hale gelmesi ve bu bağlamda estetize edilerek sunumu, yapılan literatür taraması ve bazı örnek medya içerikleri çerçevesinde tartışılmaktadır. Çalıșma kapsamı dahilinde, şimdiye değin oluşturulan bağlam ekseninde geniş kapsamlı bir literatür taraması yapılmaktadır. Böylelikle, medya içeriğinde şiddetin nasıl estetize edildiği ve nasıl alımlandığına ilişkin yapılacak ardıl çalışmalar için kuramsal bir altyapı oluşturmak amaçlanmaktadır.

Anahtar Kelimeler: Şiddet, Medya, Şiddetin Pornografisi, Şiddetin Estetiüi, Fantażmagorya.

\section{An Argumentative Study on Presentation of Violence in Media Content}

\section{Abstract}

Violence has been encountering as a phenomenon which is a part of daily life in both traditional and digital media. Consequently, neither the existence of violence in the media nor the debates on this subject are new. On the other hand, the presentation of violence in fictional content should be viewed from a different point of view, especially in the context of aesthetization. One of the existing realities is that the individual is often exposed to violent media messages during the day, not with standing the controversies over the causes that lead to violence and aggression as part of human nature and / or to exert an aggressive attitude and behavior. These messages are often presented in an aesthetized form and are interpreted pornographically by the audience. At this point, the audience can neither prevent themselves from watching violent content, nor they can escape from critical thinking. In this study, a theoretical framework on the presentation of violence in media content is formed. First, the concept of violence is handled with its etymological dimension, and then the approaches that question why and how violence and aggression exist in human nature are evaluated. Subsequently, the media content which constitutes the focal point of the study and the presentation of the violence by aesthetizing it in the context of the media are discussed within the framework of the literature review and some examples.No analysis or field survey is included in the research, however, a comprehensive literature review has been conducted in the context. In this way, it is aimed to create a theoretical infrastructure for successive studies on how the violence is aesthetized in media content and how it is recepted by the audiences.

Key Words: Violence, Media, Pornography of Violence, Aesthetics of Violence, Phantasmagoria

\section{Atıf İçin / Please Cite As:}

Erdem, M. N. (2020). Medya içeriğinde şiddetin sunumu üzerine argümantatif bir çalışma. Manas Sosyal Arastırmalar Dergisi, 9(2), 1198-1217.

Geliş Tarihi / Received Date: 14.02.2019

Kabul Tarihi / Accepted Date: 14.10.2019 


\section{Giriş}

Şiddet olgusu, özellikle de medya içeriği bağlamında değerlendirildiğinde, üzerinde oldukça uzun zamandır tartışılan bir sorunsal alandır. Bu durum, gerek şiddetin izlerkitle üzerindeki etkilerinin ölçümlendiği -başta Kültürel Göstergeler ve Ekme Kuramı olmak üzere- çalışmalarda, gerekse izlerkitlenin medya kullanım alışkanlıklarını derinlemesine inceleyen -Kullanımlar ve Doyumlar gibi- yaklaşımlarda kendini göstermektedir. Söz konusu yaklaşımlar, şiddetin insanlık tarihindeki uzun süreli varllğı karşısında ve iletişim bilimlerinin gelişim seyri dolayısıyla esasen oldukça yeni kalmaktadır. Zira şiddetin tarihi, bizzat insanlık tarihi kadar uzun bir geçmişe sahiptir. Şiddetin seyirlik hale getirilmesine dayalı ilk izler ise, insanların birbiriyle olan ilk etkileşimlerine kadar götürülebilmektedir. İnsanın kendi türüne yönelik uyguladığı şiddet, iktidarın gücü, gücün ispatı, ikame bir doyum duygusu yaratımı ve / veya basitçe eğlence amaçlı olagelmiştir (Oskay, 2000; Türkoğlu, 2007). Seyirlik ve politik uygulamalar olarak tarihe geçen gladyatör dövüşlerinin amfiteatrlarda kısıtlı sayıda izleyicinin ilgisine sunulmasından, bugünün fütursuz ve denetimi zor dijital dünyasında sayısız bireye ulaşan gerçek ya da kurgusal şiddet imgelerine değin, insanlık tarihi sayısız kere şiddetin görsellerine, hiç değilse imalarına şahit olmuştur. Birey ya şiddeti uygulayan, ya şiddetin mağduru olan veya şiddete tanıklık eden bir konumda bulunagelmiştir.

21. Yüzyll ise şiddetin belki en çok yaşandığ1 değil, ancak en görünür olduğu dönem olarak tanımlanabilir. İletişim teknolojilerinde söz konusu olan gelişmeler, kurgusal ya da gerçek, çok sayıda şiddet temelli medya içeriğinin geniş kitlelere yayılmasına neden olmuştur. Akıner'e göre (2014, s. 2) bu duruma, şiddetin 21. yüzyılda kitle iletişim araçlarına taşınarak daha büyük kitlelere seyirlik hale gelmesi neden olmuştur. "Öyle ki her gün televizyonlarda cinayet, aile içi şiddet, kadına ya da çocuğa yönelik şiddet, töre cinayeti, kan davaları, intihar, namus cinayeti gibi sayısız şiddet haberleri izlenebilmektedir. Üstelik bu tür şiddet olaylarına haberler dışında dizilerde, kadın programlarında hatta çizgi filmlerde bile rastlanabilmektedir" (Akıner, 2014, s. 2-3). Bu noktada medya her ne kadar șiddet içeren yayınları dolayımlama konusunda suçlu ilan edilse ve eleştirel çalışmaların odağına yerleştirilse dahi, geniş bir seçim yelpazesi içerisinde şiddet içeriğine yönelen izlerkitleyi anlamaya çalısan, Kullanımlar ve Doyumlar, Kültürel Çalş̧malar, yanı sıra Almmlama Çalışmalar gibi gelenekler kapsamında gerçekleştirilmiş çok sayıda araştırma da bulunmaktadır. "Dijital efekt teknolojilerindeki yeni gelismeler, bilgisayar oyunlarmm patlaması ve kâr güden medya boldinglerinin gittikese artan birleșeleri benzeri görülmemis bir vahşetle şiddeti zorlamaktadrr. Bu, belki cok da tesadïfi olmayan bir biçimde, gerçek yașamdaki felaketlerin ekran için yaratilanlardan pek ayırt edilemediği taribi bir zamanda meydana gelmektedir. Halkin birçok biçime sabip olan şiddet imgelerine karşı duyduğu aģlık, şiddeti yapımın başlica öğesi haline getirmiştir" (Trend, 2007, s. 16). Eşdeyişle, medya -özellikle de ticari açıdan kâr elde etme amaçlı olmaktan kaynaklanan bir izlenme oranı ve / veya tiraj kaygısı nedeniyle- şiddeti hemen her türden içerikte işlemekteyken; izlerkitle de bakışını bu tür içerikten çevirmemekte, ona ilgiyle yaklaşmaktadır. Bu noktada, özellikle bedensel bütünlüğü bozma amaçlı olarak, bilinçli ve kasıtlı uygulanan şiddet türlerinin görsel ve işitsel anlatılarda işlenişi yanı sıra izlerkitle tarafından alımlanışına yönelik bakış açısı, Baudrillard (2004) ve Sontag (2004) gibi isimlerce "şiddetin pornografisi" olarak tanımlanmaktadır. Bu durum genel anlamda cinsel aktivitelerin açıkça gösterildiği farklı türde medya içeriklerinin ötesinde, acı çeken insan bedenlerinin gösteriliş ve alımlanışının da pornografik olduğu anlamını taşımaktadır. Zira bu noktada söz konusu olan, şiddet mağduru bedenin ve şiddet eyleminin artalanının teşhiri ile izleyicinin bu teşhir karşısındaki hazzıdır. Trend, bu durumu medya içeriğinde yer alan şiddetin aşırllı̆̆ üzerinden tartışmaktadır. O'na göre, "medyada şiddet yok olmayacaktır ve durdurmak için gösterilen çabaların başarılı olması da olası değildir. Maddi aşırıllk ve gereksiz seks görüntüleri gibi şiddet de güçlü bir hayal sistemine dayanan ticari bir yap1 içerisinde bulunmaktadır. Kabul etsek de etmesek de, bu hayaller insanların en derinlerde bulunan arzu ve korkularılla bağlantılı oldukları için ilgi ve popülerlik kazanmaktadır” (2007, s. 19). Weaver ve Wilson, çalışmalarında medyada şiddet içeriğinin yoğunluğunun nedenlerini sorgulamaktadırlar. Onlara göre medyada yoğun bir şiddet içeriği vardır ve medya tarafindan bu durum izleyici talebi olarak savunulmaktadır. Bu noktada, şiddet içerikli programların çekici olmasının birden çok nedeni olabilir. Ancak bu nedenlerin odak noktasında "haz" bulunmaktadır (Weaver ve Wilson, 2009, s. 443). Krahé vd. (2011, s. 631), medyadaki şiddet içeriğinden alınan "hazzın”, bu türden içeriklere maruz kaldıkça artacağına vurgu yapmaktadırlar. Bu türden bir şiddet çoğu kez gündelik hayata aktarılmamakta, medyadaki içeriğe tanıklı etmekle yetinilmektedir ki, bu da ikame bir doyum duygusu yaratmada hayli etkindir (Girard, 2003; Oskay, 2000; Türkoğlu, 2007).

Şiddetin pornografik sunumu ya da alımlanması antik çağlardan bugüne değin farklı biçimlerde karşımıza çıkmıştır ve çıkmaya da devam etmektedir. Bugünü geçmişten ayıran ince çizgi ise öncelikle ulaşılan izlerkitlenin büyüklüğü, ikinci olarak da gerçeklikten kurgusallı̆̆a doğru geçiştir. Ancak insan her 
daim, kendi türüne olan şiddete ilgi ve tiksintiyle karışık bir haz duygusuyla bakmaktadır. Diğer bir deyişle, izleyici ne kendini şiddet yüklü içerikleri izlemekten alıkoyabilmekte, ne de eleştirel bakmaktan kaçabilmektedir. Sontag (2004, s. 96) bu durumu "zihinsel bir çatışma" olarak nitelemektedir.

Bu noktada vurgulanması gereken bir diğer konu medya içeriğinde yer alan şiddetin estetize edilerek sunulmasıdır. Oldukça tartışmalı olan "estetik" kavramı, her ne kadar evrensel yasalar dahilinde sanatta ve hayatta güzelliğin kuramsal bir biçimde ele alınmasını içeren bir bilim dalı olsa dahi; gündelik hayatta göze hoş gelen ve bireyde haz duygusu yaratan şeyler için de kullanılmaktadır. Bu durum medya içeriğinde yer alan şiddetin sunumunda da böyledir. Çalışma kapsamında ele alındığı haliyle, medyada insan bedeninin bütünlügünün bozulmasını aktaran görseller ya da bu minvalde oluşturulan anlatılar estetize edilerek sunulmaktadır. Böyle bir yaklaşımın temel nedenlerinden biri öyle görünmektedir ki, izlerkitlenin şiddet içeriğine olan meylinde yatmaktadır. Yine Sontag'a dönülecek olunursa; "Ceekici bir bedenin zedelenmesi, parçalanması ya da bozulmasm sergileyen bütün görüntüler -belli bir dereceye kadar-pornografiktir. Fakat tiksindirici görüntüler de pekâlâ akel çelici olabilir. ... Birçok insan için, ıstrrap verici bir şey görme isteğinin çekiciliği de ayn derecede kuvvetli bir etkendir (2004, s. 96). İnsan, kendi türüne uygulanan şiddete tanıklık etme konusunda hayli ilgilidir, -hatta Freudyen bir bakış açısıyla ${ }^{2}$ kendi içgüdüsel eğilimlerini bu tanıklıkla doyuma ulaştırmaktadır- ancak aynı zamanda bu tanıklığın beraberinde getirdiği bazı sonuçlar olmaktadır. Her şeyden önce, insan kendi uyguladığ 1 ya da kendi türünden varlıklar arasındaki şiddetin sonuçlarıyla yüzleşmede çok da başarılı değildir ${ }^{3}$. Birey kimi zaman bu histen kaçınmak, gerekse ortaya çıkan durumun yasal yükümlülükleri karşısında ceza almamak için ya da daha farklı nedenlerle, şiddet eyleminden kaçınmaktadır. Her ne kadar medya içeriğinde yer alan şiddet kimi zaman şiddeti tetikleyen bir unsur olagelse de, izlerkitle çoğunlukla izlemekle yetinmektedir. Dolayısıyla, -yine Freudyen bir bakış açısıyla ele almak gerekirse- içgüdüsel olarak kendinde bulunan şiddet ve saldırganlığı, fantazmagorik ortamlarda törpülemeye çalışmaktadır (Oskay, 2000). Bilmektedir ki, medyada yer alan şiddet her ne kadar gerçekliğe dayalı olsa da kurgusal bir yönü mutlaka vardır; dahası şiddete tanıklık ederek ikame doyuma ulaşmada sınırları belirleyen kendi iradesidir ${ }^{4}$. Diğer bir deyişle, gerçek hayatta bir kez başladığı an çoğu kez durdurulamayan ve ciddi sonuçları olan şiddet; medyada televizyon kumandasının kapama tuşuna basarak, gazetenin sayfası çevrilerek veya internet sayfası kapatılarak sonlandırılabilir. Dahası medyada şiddete tanıklık etmek ona yasal, toplumsal ya da vicdani bir yaptırımda da bulunmamaktadır. Zira medya şiddeti kimi zaman gerçek olaylar da işlense- kurgusaldır ve aynı zamanda estetize edilmiş olması, özellikle şiddetin sonuçlarılyla yüzleşmede etkindir.

Bu bağlamda bu çalışmada, ilk olarak şiddetin insanda neden ve nasıl tezahür ettiğine dayalı çalışmalar ele alınmaktadır. Ardından şiddetin pornografik sunumu ve estetize edilmesine dayalı bir bakış açısı oluşturulmaya çalışılmaktadır. Bu çalışmanın amacı izlerkitle üzerinde bu bağlamda bir etki araştırması yapmak ya da şiddetin pornografik sunumu ya da estetize edilmesi üzerine bir çözümleme yapmak değildir. Bununla birlikte, yapılacak araştırma ve çözümlemelere kuramsal bir temel oluşturulmaya çalışılmaktadır.

\section{İnsan Doğasının Karanlık Yüzü: Saldırganlık Ve Şiddet}

Türk Dil Kurumu (TDK) tarafından; "Bir hareketin, gücün derecesi, yeğinlik, sertlik"; "hız"; "bir hareketten doğan güç"; "karşıt görüşte olanlara kaba kuvvet kullanma"; "kaba güç"; "duygu veya davranışta aşırllık" (Web2) şeklinde tanımlanan şiddet kavramı, sosyal bilimler alanının en çok tartışılan ve yorumlanan kavramlarından biridir. Özellikle sosyoloji, antropoloji, psikoloji ve sosyal psikoloji gibi alanlarda şiddetin ne olduğu, nereden kaynaklandığı, dahası toplumlara ve kültürlere göre nasıl farklılıklar gösterdiği, yanı sıra şiddet içeren davranışların mevcut / olası bireysel ve toplumsal sonuçlarının neler

\footnotetext{
${ }^{2}$ Freud'un bu konuya dayalı bakış açısı metnin ilerleyen sayfalarında detaylı bir biçimde ele alınmaktadır.

3 Bu durumun en çarpıcı örneklerinden biri, bir performans sanatçısı olan Marina Abramovic’in 1974 yllında sergilediği bir performanstır. Abramovic performansı esnasında sadece hareketsiz durmuş ve bir masa üzerinde yer alan çiçekten biçağa, kekten dolu bir silaha kadar yer alan çeşitli materyallerin katılımcılar tarafından kendi üzerinde kullanımına karşı durmayacağını -her ne amaçla olursa olsun- belirtmiştir. İlk aşamada sorun yaşanmasa da performansın ilerleyen aşamalarında, katılımcılar sanatçıya fiziksel, cinsel ve psikolojik şiddet uygulamaya başlamışlardır. Bu durum, aktif -ve muktedir- katılımcıların karşısında pasif -ve savunmasız- bir birey denklemini hayli kötücül yönleriyle ortaya koymaktadır. Yaklaşık alıı saatlik performans, katılımcılardan birinin dolu silahı Abramovic'e doğrultması sonucu galeri sahibinin nihayet vermesi ile sonlanır. Bu noktada asıl dikkat çekici olan, perfomansın sona erdiği an itibarıyla katılımcıların kendi uyguladığ1 şiddetten kaçmasıdır. Çoğunluk, sonuçlarını bizzat elleriyle olușturduğu bu durumla yüzleșememiș ve hatta ortaya çıardığı bu hasar görmüș bedeni görmekten açıç̣a korkmuștur. Söz konusu performans ile ilgili sanatçının kendi anlatımını da içeren videoya https://www.youtube.com/watch?v=kijKz3JzoD4 bağlantısından ulaşmak mümkündür.

4 Medya içeriğinin kurgusallı̆̆ı ve izleyicinin kendi sınırllıklarının bilincinde olması ile ilgili olarak Weaver ve Wilson'ın (2009)

"The Role of Graphic and Sanitized Violence in the Enjoyment of Television Dramas" başlıklı makaleleri incelenebilir.
} 
olabileceği gibi sorular cevaplandırılmaya çalışılmaktadır. Keza iletişim bilimleri de bu bağlamda şiddete dayalı bazı sorular ve cevaplar üretmeye odaklı çok sayıda çalışmanın görüldüğü alanlardan biridir. Özellikle de medya içeriğinde şiddetin gerçek ya da kurgusal sunumu bağlamında. Ancak bu konuyu ele almadan önce şiddet kavramını etimolojik açıdan irdeleyerek bir başlangıç yapmak uygun görünmektedir.

İlkin Türkçedeki yerine bakmak gerekirse; şiddet kavramı dilimize Arapça "şedid" kelimesinin evrilmesiyle geçmiştir. Şemseddin Sami’nin Kamus-1 Turkîsinde "şiddet"; sertlik, sert ve katı davranış, kaba kuvvet kullanma olarak geçmektedir. "SSedid" ise sert, katı ve şiddetli anlamlarına gelmektedir. Ali Püsküllüoğlu'nun Türkçe Sözlüğü’nde ise kavram TDK tarafindan yapılmış yukarıda verilen tanımlamalarla paraleldir. Avrupa dillerine, özellikle de İngilizce ve Fransızcaya bakıldığında ise sözcüğün Latince "violentia" kelimesinden türediğini ifade etmek mümkündür. İlk olarak Fransızcada kullanılmaya ve ardından Ortaçağ İngilizcesinde görülmeye başlanmıştır. Latince "vis" kökünden türeyen "violentia" sözcüğ̈̈, çeşitli anlamlarının yanı sıra; "güç", "erk", "şiddet" ve "bedensel gücü” simgelemektedir (Ünsal, 1996, s. 29). Oxford Dictionary, (Türkçe karşllığ şiddet olan) "violence" kavramını "bir kimseyi ya da bir şeyi incitmek, ona zarar vermek ya da onu öldürmek için tasarlanmış olan fiziksel gücü içeren davranış", "fiziksel zor kullanma ya da tehdit, büyük bir gücün sergilenmesi ile kanuna aykırı davranışlar göstermek", "duygu gücü veya yıkııı bir doğal güç" şeklinde tanımlamaktadır (Web3). Fransızcada da, İngilizce yazılımı aynı olan kavram yine benzer anlamlarda kullanılmaktadır. "Bir kişiye, güç veya baskı uygulayarak isteği dışında bir şey yapmak ya da yaptırmak; şiddet uygulama eylemi, zorlama, saldırı, kaba kuvvet, bedensel ya da psikolojik acı çektirme ya da işkence, vurma ve yaralama" olarak tanımlanmaktadır (Ünsal, 1996, s. 29). Sözcüğe atfedilen anlamlara bakıldığında, "güce" yapılan bir atıf olduğu görülmektedir. Ancak buradan salt güç sahibi olmanın şiddete yol açtığı anlamı çıkarılmamalıdır. Şiddet, insan gücü söz konusu olduğunda, bunun zarar verici bir veya bir dizi eyleme dönük kullanımını ifade etmektedir.

Bu bağlamda kavramsal açıdan şiddet; güç, baskı ve zor kullanma yoluyla fiziksel veya mental zarar vermeye neden olan eylem, yaklaşım, tutum ve/veya söylem olarak tanımlanabilmektedir. Bu nedenle, sadece kaba kuvveti içeren tutum ve davranışlar değil, aynı zamanda sosyal alanda özgüven ve öz saygıyı tahrip eden ifadeler, tutumlar ve davranışlar, hakaret, aşağılama, tehdit ve ekonomik kısıtlama içeren korku yaratma, endişe ve huzursuzluk hissi yaratma, özgürlüğü kısıtlama veya birini bir şey yapmaya zorlama da şiddetin tanımına aittir. Bu noktada, fiziksel, cinsel, duygusal, sözel, ekonomik ve siyasal olmak üzere birçok şiddet türünü fark etmek mümkündür (Yüksel, 2004, s. 36). Son bir tanım daha vermek gerekirse; "bir karşıllkel ilişkeiler ortamında taraflardan biri ya da birkaģ doğrudan veya dolayl, toplu ya da dağgntk olarak. diğerlerinin veya birkaģmn bedensel bütünlügüne veya törel, ablaki / moral / manevi bütünlügüne veya mallarna veya simgesel ve sembolik. kültürel değerlerine oram ne olursa olsun zarar verecek şekilde davramrsa orada şiddet vardir" (Michaud, 1986'dan akt. Özerkmen, 2012, s. 5).

Şiddetin etimolojik kökenine genel bir bakışla, kavramın ortaya çıkışııı ve kitabî tanımlarını bu şekilde özetlemek mümkündür. Eylemsel ve anlatısal bağlamda geriye dönük izlerini ise, insanın dünya üzerinde ilk ortaya çıktığı dönemlere, mağara duvarlarına resmedilen av sahnelerine değin sürmek mümkündür. Şiddet, bireysel ya da toplumsal olarak insan hayatında hep var olmuştur ve varlığını da sürdürmektedir. Bununla birlikte, farklı bilim dallarınca ya da düşünürlerce farklı boyutlarda yorumlanmıştır. Kimi zaman bireyin genlerinde yer alan biyolojik bir unsur, kimi zaman içsel bir dürtü, kimi zaman öğrenilen bir davranış, kimi zaman insanlık tarihinde kurumların (devlet, din vb.) ortaya çıkışı ile paralel bir çatışma ortamının sonucu olarak görülmüş; legal ya da illegal olup olmadığ1 veya neye / kime göre legal / illegal olduğu üzerine ciddi tartışmalar yürütülmüştür ${ }^{5}$. Sözgelimi, masum bir bireyin öldürülmesi tarihin hemen her döneminde cinayet, vahşet ve şiddetin en üst düzeylerinden biri olarak görülmüş; oysa -bazı dinlerce yasaklanmış, kimi zaman da hayvanlarla ikame edilmiş olsa da- çok tanrılı dinlerin hakim olduğu dönemlerde tanrılara aynı masumluktaki bireylerin kurban olarak sunulması kutsal olarak kabul edilmiş ve hatta eylem yüceltilmiştir. Şiddetin çağlar içerisinde algılanışı da farklılık arz etmektedir. Örneğin özgürlük, eşitlik ve adalet arayışı ile sembolize edilen Fransız İhtilali binlerce kişinin giyotinle idam edilmesini beraberinde getirmiş, ancak bu idamlar sürecin doğal bir parçası ve kabul edilebilir görülmüş, dahası seyirlik hale getirilmiştir. Bugün ise idam cezalarının seyirlik olması bir yana, adalet sisteminde var olması dahi insan haklarına aykırı görülmektedir ve çoğu Batılı ülkede de bu cezalandırma türü kaldırılmış durumdadır. Öte yandan şiddet dendiğinde, genelde akla ilk gelenin insanın kendi türüne yönelik eylemleri olması da ilginçtir. Tamamen zevk için yapılan avcilığın spor olarak görülmesi, İspanya başta olmak üzere belli başlı ülkelerde halen çok popüler olan boğa güreşlerinin sürdürülmesi, hayvanat bahçelerinde tutsak

\footnotetext{
${ }^{5} \mathrm{Bu}$ tartışmalar ile ilgili bilgi çalışmanın "Şiddet ve Saldırganlığı Anlamaya Yönelik Kuramsal Çalışmalar” başlıklı kısmında yer almaktadır.
} 
edilen ve kötü koşullarda seyirlik birer nesne haline getirilen hayvanların varlı̆ğ, sirkler ya da yunus ve “orka"ların gösteri yapmalarının sağlandığı sözde eğlence merkezlerinin salt ticari amaçlarla varlığını sürdürmeye -son yillarda sayısı giderek artan boykot ve protestolara rağmen- devam etmeleri, veya sadece ve sadece bir insanın kıyafetini daha gösterişli hale getirebilmesi için kullanılmak üzere kürklerin elde edilme yöntemleri de şiddet tanımına dahildir. Özellikle son yıllarda bu türden eylemlere karşı giderek artan bir bilinçlenme ve karşı duruştan söz edilebilir olmakla birlikte; yine ve yeniden hayvanlar insan türünün elinden acı çekmeye devam etmektedir. Öyle görünmektedir ki insan, hayvanlara karşı eziyet etmeyi normalleştirmekte, hatta avcıllğı spor olarak nitelendirirken, boğa güreşlerinde -en az iki gün önceden işkence görmeye başlamış ve doğal olarak saldırgan hale gelmiş bir boğayı, (sözde) güçlü ve medeni insanın karşısına çıkarırken, gösteri merkezlerinde yer alan canlıları ehlileştirmiş olmayı vurgularken; aslında doğaya karşı nasıl bir üstünlük sergilediğini de vurgulamış olmaktadır. Bu ve benzeri örnekler hiç şüphesiz çoğaltılabilir niteliktedir. Ancak bu noktada vurgulanması gereken bir diğer unsur, şiddetin kayıt altına alınarak (ya da sözlü bir biçimde) aktarılan bir özelliğe de sahip olmasıdır. Gerçek ya da kurgusal olarak... Ki bu da bizi şiddetin nasıl seyirlik hale geldiği sorusuna yönlendirmektedir. Ancak bu sorunun cevabi, çalışmanın ilerleyen sayfalarında yer almaktadır ve bu soruyu cevaplamanın ilk adımı da "şiddet"in bir kavram ve olgu olarak biraz daha detaylı irdelenmesidir.

Yukarıda ifade edildiği üzere şiddet, insanlığın ilk var olduğu dönemlerden bu yana şu ya da bu şekilde varlığını sürdürmektedir ve pek çok farklı biçimde karşımıza çıkmaktadır. "Histoire de la violence" başlıklı çok kapsamlı bir incelemenin yazarı olan Fransız araştırmacı Jean-Claude Chesnais uluslararası polis örgütü Interpol'ün sınıflandırmasını esas aldığı tipolojisinde şiddet türlerini sınıflandırmaktadır (Ünsal, 1996, s. 32). Söz konusu sınıflandırmayı aşağıda görüldüğü şekliyle tablolaştırmak mümkündür:

Tablo 1. Siddet Türleri

\begin{tabular}{|c|c|}
\hline Özel Şiddet & Kollektif Şiddet \\
\hline $\begin{array}{l}\text { 1. Cürümsel Şiddet } \\
\text { a. Ölümle Sonuçlanan: Cinayetler, suikastler, zehirlemeler } \\
\text { (ebeveyn ya da çocuk öldürmeleri de dahil), idamlar, vb. } \\
\text { b. Bedensel: Bilerek darbe ve yaralamalar } \\
\text { c. Cinsel: Irza geçme }\end{array}$ & $\begin{array}{l}\text { 1.Vatandaşların İktidara Karşı Şiddeti } \\
\text { a. Terör } \\
\text { b. Grevler ve İhtilaller }\end{array}$ \\
\hline $\begin{array}{l}\text { 2. Cürümsel Olmayan Şiddet } \\
\text { a. İntihar (İntihar veya intihar teşebbüsleri) } \\
\text { b. Kaza (Araba kazaları da dahil olmak üzere) }\end{array}$ & $\begin{array}{l}\text { 2. İktidarların Vatandaşlara Karşı Şiddeti } \\
\text { a. Devlet Terörü } \\
\text { b. Endüstriyel Şiddet }\end{array}$ \\
\hline & 3. Son Kertede Şiddet: Savaş \\
\hline
\end{tabular}

Kaynak: Ünsal, 1996, s. 32

Chesnais tarafindan yapılan bu sınıflandırma bütünüyle, somut aktörler tarafindan gerçekleștirilen somut şiddet eylemlerini kapsamaktadır. Polat, şiddeti değerlendirirken şiddete maruz kalan, şiddeti yaşayan gruplara göre bir sınıflama yapıldığında temel olarak; kadına yönelik şiddet, çocuğa yönelik şiddet, yaşlıya yönelik şiddet, akranlar arası şiddet, kardeşler arası şiddet, flört şiddeti, engellilere yönelik şiddet, LGBT şiddeti, mülteci şiddeti ve kişinin kendine yönelik şiddeti şeklinde karşımıza çıktı̆̆ını belirtmektedir. Ayrıca Polat'a göre (2016, s. 16 - 17) uygulanan şiddet tipine göre yapılan sinıflamada yer alan şiddet türleri; fiziksel, cinsel, duygusal, ekonomik ve siber olmak üzere sıralanmaktadır. Elbette bu şiddet türleri, kendi içlerinde daha detaylı biçimde sınıflara ayrılabilmektedir. Bu çalışmada odaklanılan ise fiziksel şiddettir. Özellikle de bedensel bütünlüğü bozma amaçlı olarak, bilinçli ve kasıtlı şiddet türleri kapsamında bir bağlam oluşturulmaya çalışılmaktadır.

\section{Şiddet ve Saldırganlığı Anlamaya Yönelik Kuramsal Çalışmalar}

Şiddeti tanımlama çabası, büyük ölçüde onun nereden kaynaklandığını bulma çabalarını da içermektedir. Bu konuda fen bilimleri ve sosyal bilimler alanında pek çok çalışma yürütülmüştür ve doğal olarak görüş ayrılıkları da bulunmaktadır. Kimi yaklaşımlar şiddetin ve saldırganlığın içgüdüsel olduğunu iddia etmekte, kimileri öğrenilen davranışlar olduğunu savunmaktadır. Kimi yaklaşımlarda ise genetik faktörlerin söz konusu olduğu vurgulanmaktadır. Bu noktada kesin bir doğrudan söz etmek çok da mümkün görünmemektedir, zira her bir yaklaşım derinlemesine araştırmalarla ortaya konmuştur ve belirli bir haklılık payı da içermektedir. Bu nedenle, çalışmanın bu kısmında şiddet ve saldırganlı̆̆ ele alan çalışmalar, genel kapsamda kısaca ele alınmaktadır. 
Saldırganlık sonucu ortaya çıkan şiddet davranışlarının nedenlerini sorgulama çabalarını ve bu nedenleri açıklamaya dayanan kuramları sekiz ana başlıkta değerlendirmek mümkündür (Gök, 2009, s. 14 23):

- İçüdüsel Yaklaşımlar (Psikoanalitik Kuramlar)

- Dürtü Kuramları

- Kuşaklararası Geçiş Kuramı

- Akılc1 - Duygusal Kuram

- Sosyal - Bilişsel Öğrenme Kuramlar1

- Davranışç Yaklaşım

- Biyolojik Kuram

- Toplumsal ve Feminist Kuramlar

İçüdüsel yaklaşımlar bağlamında üzerinde özellikle durulması gereken yaklaşımlar Freud ve Lorenz’e aittir. Elbette bu iki isimden önce de içgüdü üzerine çalışmış belirli isimler vardır. Belki bu noktada Charles Darwin'in çalışmalarının tetikleyici olduğunu vurgulamakta yarar bulunmaktadır. Erich Fromm, Insandaki Yikuccliğm Kökenleri isimli kitabında Eski İggüdücüler olarak tanımladığı William James (1890) ve William McDougall (1913-1932) olmak üzere pek çok ismin Darwin'in Evrim Kuramından yola çıkarak çalısmalarını yaptıklarını vurgulamaktadır. Bu isimler, tek tek her bir içgüdünün yönlendirdiği varsayılan davranış türlerini içeren uzun listeler oluşturmuşlardır ${ }^{6}$. Fromm ortaya konan bu yaklaşımların her birinin kuramsal açıdan zengin ve hiçbir zayıflığı olmayan oldukça gelişkin yapıtlar olduğunu ifade etmektedir. Özellikle McDougall'ın yaklaşımı Freud'un yaklaşımına geçişte deyim yerindeyse bağlayıcı bir köprü niteliği taşımaktadır ${ }^{7}$. Ancak Freud'un yaklaşımının O'nu aşan bir ileri adım niteliği taşıdığını da vurgulamaktadır. Freud'un bu ileri adımı, bütün "içgüdüleri” -cinsel içgüdüler ve kendini koruma içgüdüsü olmak üzere- iki sınıfta birleştirmiş olmasıdır (Fromm, 1993, s. 34). Ancak bu görüşü 1920'li ylllardan sonra değişmiştir. İlk aşamada cinsellik içgüdüsü (libido) ile kendini koruma içgüdüsünün diğer tüm güdüleri kapsayan ve insana egemen olan unsurlar olduğunu ileri sürmüştür. Ancak özellikle de 1. Dünya Savaşı'nın yıkıcıllğına ve ölümcüllüğüne şahit olan Freud bu savını değiştirmiş, kendini koruma içgüdüsünden öte insanda bir saldırganlık güdüsü olduğunu ileri sürmüştür (Kahn, 2016, s. 34). Freud insanların kendilerine zarar vermek için içgüdüsel bir istek duyduğunu belirtmiştir. Ancak güçlü bir benlik, kişinin kendisini yok etmesine izin vermeyeceği için bu içgüdünün başkalarına yönlendirildiğini ileri sürmüştür (Yavuzer, 2013, s. 48). Buna göre insana egemen olan iki temel dürtü bulunmaktadır: Yapıcı cinsel enerji (Eros) ${ }^{8}$ ve yıkıc1 saldırganlık enerjisi (Thanatos) ${ }^{9}$. Freud, yeni kuramsal evreyi şu sözlerle tanımlamıştır: "Yaşamm başlangıcina iliskin yorumlardan ve biyolojik koşutluklardan yola ģ karak, yasayan maddeyi korumaya yönelik icgüdünün yam sira bu bilimleri parçalamaya ve onlar yeniden ilkel, inorganik durumlarnna döndürmeye çabalayan, öncekine karşst bir başka

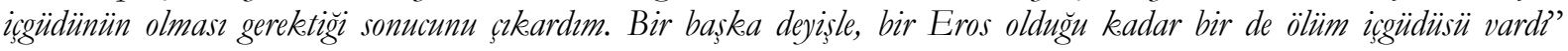
(Freud, 1930'dan akt. Fromm, 1993, s. 34). Freud'un bu söyleminden her ne kadar, Eros ve Thanatos'un karşıt güçler olduğu sonucuna varılabilir olsa da, esasen ortaya hem bir çatışma hem de uzlaşı çıkmaktadır. Hayatın bizzat kendisi, yaşam ve yaşamın ortaya çıkardığ gerilim ile bu gerilimin nihai tahliyesini içeren bir danstir (Cho, 2006, s. 20).

Lorenz’in görüşleri de Freud ile paralellik göstermektedir. O’na göre, insan saldırganlığı, sürekli akan bir enerji pınarının beslediği bir içgüdüdür ve dış uyaranlara karşı bir tepkinin sonucu olması gerekmemektedir. Lorenz, içgüdüsel bir harekete özgü enerjinin, o davranış kalıbıyla ilişkili sinir

\footnotetext{
6 Örneğin James'in öykünme, rekabet, kavgacılık, duygudaşlık, avcılık, korku, elde etme, hırsızlık, yapıcılık, oyun, merak, toplumculuk, gizlemecilik, temizlik, alçakgönülllülük, sevgi ve kıskançlık içgüdüleri -evrensel insan nitelikleri ile toplumsal olarak koşullandırılmış özgül kişilik eğilimlerinin garip bir karışımı- bu davranış türlerindendir (Fromm, 1993, s. 33).

${ }^{7}$ McDougall, içgüdüyü bir "motor mekanizma”yla ve değişmez biçimde sabitleşmiş bir motor karşılıkla özdeşleştirmemiştir. Ona göre, bir içgüdünün özü bir "doğal eğilim”, bir "arzu”dur ve her bir içgüdünün bu duygusal-doğuştan özü, “toplam içgüdü düzeninin hem öğrenmeyle ilgili, hem de motor kısımlarından göreceli olarak bağımsız hareket edebilme yeteneğinde görünmektedir” (McDougall, 1932'den akt. Fromm, 1993, s. 33).

${ }^{8}$ Eros: Yunan mitolojisinde Afrodit’in Ares ile olan evlilik dışı ilişkisinden doğan dört çocuğundan biridir. Cinsel aşkı / tutkuyu temsil eder (Wilkinson, 2010, s. 38). Kimi zaman Eros, yaratılış mitinin en önemli unsurlarından biri olarak görülmektedir. Bu görüşe göre, Zeus'un bile korkuyla karışık saygı duyduğu bir tanrıça olan siyah kanatlı Gece'ye, Rüzgar tarafindan kur yapılmıştır. Rüzgar, gümüş yumurtasını Gece'nin rahmine bırakmış, yumurtadan bazılarının Phanes dediği, Eros ortaya çıkarak evreni yaratmıştır. Her ne kadar altın kanatlı ve güzel bir melek görünümünde resmedilmekteyse de, temsil ettiği cinsel tutkunun toplumsal düzeni bozabilecek kadar tehlikeli olduğundan korkulmaktaydı (Graves, 2010, s. 69).

9 Thanatos: Ölüm. Yunan mitolojisinde yer alan tanrılardan biridir. Çok sık adı geçmeyen ancak kendisinden çok korkulan bir tanrıdır. Uyku tanrısı Hypnos’un ikiz kardeşidir (Wilkinson, 2010, s. 69).
} 
merkezlerinde sürekli olarak biriktiğini ve eğer yeterince enerji birikmişse, bir uyaran olmasa bile, bir patlamanın meydana gelmesi olasılı̆̆ı bulunduğunu savunmaktadır. Bununla birlikte, hayvanlar ve insanlar depolanmış hareket enerijisini serbest bırakacak uyaranları çoğunlukla bulmaktadırlar, uygun uyaranlar ortaya çıkıncaya kadar elleri kolları bağlı beklemeleri gerekmemektedir. Uyaran aramakta, hatta yaratmaktadırlar. Lorenz, W. Craig'i izleyerek, bu davranı̧̧ı "iştah davranışı" olarak adlandırmaktadır (Fromm, 1993, s. 36).

Dürtü kuramları açısından bakıldığında ise, Freud ve Lorenz’in görüşleri ile taban tabana bir zıtlık olduğu görülmektedir. Özellikle sosyal psikologlar, saldırganlık ve şiddet davranışlarının, basitçe içgüdülere indirgenemeyeceğini, pek çok farklı etkenin bu davranışların ortaya çıkmasında etkin olduğunu belirtmektedir. "Dürtü kuramclarnna göre saldır, yani diğerlerine zarar verme dürtïsü dis etkenlerden kaynakl bir dürtüdür. Bu yaklaşım salder konusundaki birçok farkel dürtü kuraminda sunulmaktadir. Bu teoriler dis sartlarm (engellenme ya da bedefe yönelike davranışa müdahalenin) diüerlerine zarar verme konusunda güclü bir güdüyü meydana çlkarabileceğini öne sürmektedirler" (Gök, 2009, s. 16). Bu kuramlar içerisinde en bilineni Dollard vd. tarafından geliştirilen "engellenme - saldırganlık hipotezi”"dir. Bu yaklaşıma göre, saldırgan davranışın meydana gelmesi her zaman için bir engellenmenin varllğını öngörmekte, buna karşın engellenmenin varlığı bir şekilde bir saldırganlık biçimini ortaya çıkarmaktadır. Engelin bir amaca ulaşılmasını önleyen neden olduğu düşünülürse, engellenmenin de saldırganlığı doğurabileceği açıktır (Kiraz, 2015, s. 127).

Kuşaklararası Geçiş Kuramı bağlamında bakıldı̆̆ında ise esasen bir öğrenme davranışının varllğından söz edebilmek mümkündür. Egeland'a göre istismara tanıklık eden ya da istismara uğrayan çocuk bunu erişkinliğine uygulayıcı olarak taşımaktadır. Davranış psikolojisi ve sosyal öğrenme teorilerinden bazı fikirleri birleștiren bu kuram, koşullanma ve model geliştirme süreçleri aracıllğı ile şiddetin öğrenildiğini savunmaktadır. Aile içi şiddet için bu kuram geniş olarak kabul görmüş olsa da, diğer taraftan istismar ve şiddet ortamında büyüyen çocukların çoğu istismarcı ya da şiddet uygulayıcısı olmamaktadır. Bununla birlikte normal ortamda büyüyen bir kişinin de istismarcı bir anne-baba ya da eş olmayacağı garanti edilemez. İnsanın ilerde bir şiddet uygulayıcısı olmasının sebebi, çocukluğunda şiddet temelli bir ailede olmasından kaynaklanabilmektedir (Gümüş, 2011, s. 20). Her ne kadar aile içi şiddet ve istismarın, erişkinlik döneminde şiddet ve saldırganlığ1 tetikleyeceğine dair bir genelleme yapılamayacağı bizzat Egeland tarafindan dile getirilse dahi, bugün özellikle de ABD'de işlenen cinayet ve cinsel taciz / tecavüz suçlarının faillerinin çocuk yaşta saldırı ya da istismara maruz kaldığı da bilinen bir gerçekliktir, özellikle de aile bireyleri tarafindan.

Şiddet ve saldırganlık bağlamında ele alınabilecek olan bir diğer yaklaşım "Akılcı - Duygusal Kuram"dır ve bu kuram A-B-C teorisine dayanmaktadır. Söz konusu teoriye göre; bireyler bir olay yaşarlar (A) ve bu olaya duygusal ve davranıssal bir tepki verirler (C). Görünürde verilen bu tepki (A)nın sonucu olarak ortaya çıkmaktadır; fakat burada (C)ye neden olan (A) değildir. (C)nin kaynağı (A) olarak görülmekle birlikte gerçek anlamda (C)ye neden olan bireyin inanç sistemi (B)dir. (A), hoş bir olay olduğunda, buna ilişkin inançlar çoğunlukla zararsız ve tehlikesizdir. Buna karşın (A) hoş bir olay olmadığında, akılcı olmayan inançlar gelişebilir. Bunlar da çoğunlukla rahatsızlık verici duygusal ve davranışsal sonuçlara neden olmaktadırlar (Sharf, 2000'den akt. Gençtanırım ve Voltan - Acar, 2007, s. 30). Corey, bu durumu aşağıda görüldüğü şekliyle modelleştirmiştir. Bu teori ve model sonrasında Ellis tarafından geliştirilerek "Akılc1 - Duygusal Kuram” ortaya çıkmış ve bir terapi yönteminin de geliştirilmesini sağlamıştır.

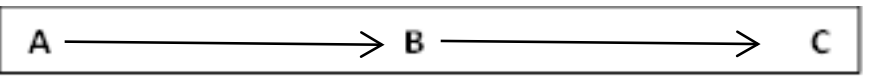

Şekil 1. $A-B-C$ Teorisi

Kaynak: Corey (1996) Akt: Gençtanırım ve Voltan-Acar, 2007, s. 30

Sosyal psikologlarca en rağbet gören bakış açısı ise şiddet ve saldırganlığın öğrenilmekte olduğudur. Baron ve Richardson (1994), Berkowitz (1993) ve Geen (1998) başta olmak üzere çoğu bilim insanı, filozof ve düşünür, şiddet ve saldırganlığın öğrenilen davranışlar olduğunu savunmaktadır (Aronson vd., 2010, s. 676). Ancak bu isimlerden önce Bandura tarafindan yapılan çalışmalar bu bağlamda özellikle önemlidir. Bandura (1973) saldırgan davranışların öğrenildiği ve kökeninde direk ya da dolaylı çevresel deneyimlerin olduğunu ifade etmiştir ve sosyal öğrenme kuramı içgüdü kurumları ile kıyaslandığında saldırganlı̆̆ın doğuştan gelmediği, değiştirilebilir ve engellenebilir olarak görmesiyle, saldırganlı̆̆ın öğrenildiği kadar söndürülebileceğini ya da hiç öğrenilmeyebileceğini öne sürmektedir (Arslan vd., 2010, s. $381)$. 
Davranış̧̧ı yaklaşım ise daha çok uyaran - tepki süreci üzerine yoğunlaşmaktadır. Bu yaklaşım insan davranışını, dış çevredeki uyarıcılara karşı organizmanın gösterdiği tepkiler biçiminde açıklamıştır. Zihinsel süreçlerin davranış üzerindeki etkisini önemsemeyen davranışçllğın gelişiminde Pavlov, Watson, Thurndike ve Skinner önemli katkılar sağlamışlardır (Aydın, 2000, s. 184). Bu noktada Pavlov'un "klasik koşullanması" ile Skinner’in "edimsel koşullanması" ön plana çıkmaktadır. Pavlov, koşullu ve koşulsuz uyaranların öğrenme sürecine etkileri üzerine yoğunlaşırken; Skinner ödül - ceza sisteminin davranışın öğrenilmesinde ve uygulanmaya devam edilmesindeki pekiştirici ya da caydırıcı rolü üzerine önemli çalısmalar ortaya koymuştur. Şiddet ve saldırganlık açısından bakıldığında "davranış psikolojisine göre, şiddet içeren davranış kurbanın bu davranışa karşı esneklik göstermesi ile güçlenir” (Gök, 2009, s. 21). Bu durum bireysel ya da toplumsal bağlamda geçerlidir. Diğer bir deyişle, şiddet ve saldırganlık kurban ya da saldırganın çevresince veya toplumsal bağlamda hoş görüldüğü sürece davranış pekişir ve bir alışkanlığa dönüşür. Cezalandırma sistemi ise davranışın engellenmesi aşamasında etkin olmaktadır.

Öte yandan şiddet ve saldırganlığın kaynağının insan bedeni olup olmadığı, diğer bir deyişle insan genlerinde bu unsurların olup olmadığ da ciddi anlamda bir tartışma konusudur. Aronson vd., hormonal dengesizliklerin saldırganlık davranışlarının ortaya çıkışında önemli birer etken olduğunu vurgulayan çalışmalara işaret etmektedirler. Bu çalışmalar grubundan ilki serotonin eksikliğinin şiddet eylemlerini doğurabildiğini ortaya çıkarmıştır. Serotonin yalnızca orta beyinde ortaya çıkmaktadır ve itkisel saldırganlık üzerinde engelleyici bir etkiye sahiptir. Hayvanlarda serotonin akışı engellendiğinde bunu genellikle saldırgan davranışlar izlemektedir; Davidson, Putnam ve Larson (2000) tarafindan yürütülen çalışmada, insanlarda şiddet içerikli suça yönelik davranışların özellikle az miktarda serotonin üretimi ile bağlantılı olduğunu bulunmuştur. Ayrıca Bjork, Dougherty, Moeller, Cherek ve Swann (1999) tarafindan, normal insanlar üzerinde yürütülen laboratuvar deneylerinde doğal serotonin üretiminin önü kesildiğinde saldırgan davranışların arttığı görülmüştür. Serotonin azlı̆̆1 saldırganlığa neden olduğu gibi erkeklik hormonu olan testosteronun çok fazla salgılanması da aynı sonucu doğurmaktadır. Moyer (1983) tarafından yürütülen araştırmada testosteron enjekte edilen laboratuvar hayvanları daha fazla saldırganlaşmıştır ve insanlarda da buna paralel bulgulara ulaşılmıştır. Şiddet içerikli suçlardan hüküm giyenlerde doğal testosteron düzeylerinin, şiddet içermeyen suçlardan hüküm giymiş mahkumlara oranla önemli ölçüde yükssek olduğu görülmüştür (Aronson vd., 2010, s. 684-685). Yanı sıra, şiddet ve saldırganlğ̆ın genetik aktarım yoluyla da geçebileceği yönünde çalışmalar yürütülmüştür. Suç davranışının temelinin, nesilden nesile aktarılan "kötü genler” olduğunu inceleyen 'öjenik kriminoloji’ (eugenic criminology) 1920’lerden sonra literatürdeki çalışmalarda etkin olmuştur. Bu bakış açısı özellikle 2. Dünya Savaşı'ndan sonra terk edilmiştir (Mutchnick, 2010'den akt. Özaşçılar, 2016, s. 23). Bu konuda yapılan çalışmalar içerisinde daha niceleri sayılabilirse de, saldırganlık ve şiddetin biyolojik boyutu ile ön plana çıkan bulgular bu çerçevede ağırlık kazanmıştır.

Şiddet ve saldırganlığın kaynağını sorgulayan ve bu başlık altında ele alınmakta olan son yaklaşım, toplumsal ve feminist kuramdır. Bu kuram, saldırganlığın temel belirleyici faktörünün sosyal yaşam olduğu konusunda görüş bildirmektedir. Toplumun erkek ve kadına biçtiği rol ve görevlerin şiddet yaşantısını da doğrudan etkilediğini ve erkeklerin şiddete eğilimli oluşunun kaynağını bu sosyal şartlanmışlıklar ve sosyalizasyon sürecinin belirlediğini ifade etmektedir. Bu görüşün, özellikle işsizlik, yoksulluğun artmas1, göç gibi sosyal etkilerin şiddet olaylarında artışa neden olduğuna dair tespiti genelde kabul gören bir yaklaşımdır (Gök, 2009, s. 23).

Şiddet ve saldırganlığın kaynağını açıklamaya çalışan tüm bu çalışmalar genel olarak değerlendirildiğinde, içgüdüsel, biyolojik, toplumsal ya da kültürel fark etmeksizin, öncelikle şiddetin bir olgu olarak varllğının kabul gördüğü ifade edilebilmektedir. Diğer bir deyişle, şu ya da bu şekilde şiddet vardır ve varlığı inkar edilememektedir. Şimdiye değin burada aktarılan çalışmalar -ki çalışmanın sayfa sınırlllığ1 çerçevesinde gerçekleştirilmesi zorunluluğu dolayısıyla esasen bir özet niteliğindedir- "Şiddet neden var?", "İnsanları şiddete yönlendiren sebepler nelerdir?", "Bir insanı şiddet uygulamaya iten ya da onu şiddet uygulamaktan alıkoyan unsurlar nelerdir?" minvalinden sorulara yanıt bulmaya çalışmaktadır. Bizce bu noktada sorulması gereken bir soru daha bulunmaktadır: "Şiddet sadece davranışsal olarak mı ortaya çıkar?" Ya da daha farklı bir bakış açısıyla sormak gerekirse, "Şiddete gönüllü tanıklık da şiddet içeren bir davranış mıdır ve insanların şiddete tanıklık etmeye yönelik ilgileri hangi noktada konumlandırılmalıdır?" Bu sorunun cevabı, -kanımızca- şiddetin pornografik hale gelmesinde yatmaktadır. 


\section{Medya ve Şiddetin Pornografisi Üzerine}

Yine bir dizi soruyla başlamak gerekirse; "Şiddet ne zaman gündelik hayatımızın içerisinde bu denli yer edinmeye başladı?", "Kan ve vahşetle ilgili görüntülere, yazılara, seslere olan ilgimizin patolojik boyutlara ulaşması gerçekten sandığımız kadar yeni bir olgu mu?", "Ya da bu türden içeriklere sanıldığı kadar ilgili miyiz ve durum gerçekten patolojik boyutta mı?”... Bu türden soruları çoğaltmak elbette ki mümkündür. Ve öyle görünmektedir ki şiddet ile birey arasındaki ilişki bütünüyle ikiyüzlü ve marazi bir ilişkidir. Bu türden bir savı açılama çabası kapsamında sözü edilen, elbette sözlü ya da psikolojik şiddet değildir. Daha önce de ifade edildiği üzere bu çalışmada özellikle bedensel bütünlüğü bozma amaçlı olarak, bilinçli ve kasıtlı şiddet türleri kapsamında bir bağlam oluşturulmaya çalışılmaktadır. Bu türden şiddet ile birey arasındaki ikiyüzlü ve marazi ilişkiye gelinecek olursa, hiç şüphesiz bu noktada ilk ifade edilmesi gereken, şiddete eylemsel bağlamda karşı bir duruş sergiliyor görünmemize karşın şiddet içerikli görüntülere olan ilgimizdir. Özellikle de Freudyen bir bakış açısıyla ele alındığında... Ve bu durumun ortaya çıkmasında şüphesiz ki iletişim teknolojilerindeki gelişim önemli bir pay sahibidir. Tam da bu nedenle, 21. yüzyılın ilk yirmi yılı, insanlık tarihi açısından bakıldığında şiddetin belki en çok yaşandığı değil ancak en çok görünür olduğu dönem olarak tanımlanabilir. Zira dünyanın hemen her yerinde gerçekleșen șiddet olayları, medya aracıllğıyla gündelik hayatın içerisinde yer edinmiştir ve dahası bu yerini korumaya devam etmektedir. Görsel, işitsel, görsel - işitsel tüm medyalarda, kurgusal ya da gerçek şiddet unsurları önemli yer kaplamaktadır. İletişim bilimleri gibi disiplinlerarası alanlarda da bu durum başlangıştan bu yana tartışma konusu olagelmiştir. Zira, medya kurumlarının ticarileşmesinden itibaren tiraj ya da rating kaygısı ile kitlelerin ilgisini çekecek türden yayın yapma anlayışları bir yana, kitlelerin neden bu türden içeriğe ilgi duyduğu da tartışılması gereken konulardandır, öyle de olmuştur. Örneğin bir yandan Gerbner ve arkadaşlarının 1960’ı yılların ortalarında başlattıkları "Kültürel Göstergeler Projesi”'10, şiddetin, toplumsal düzenin anlatımında kilit nokta olduğunu savunmalarına yol açacak veriler elde edilmesini sağlamıșken; "Kullanımlar ve Doyumlar"11 gibi izleyici temelli yaklaşımlar, izleyicinin içeriği kendisinin seçtiğini ve sanılanın aksine kitle iletişimi sürecinde oldukça aktif bir rolü olduğunu savunmaktaydı. Diğer bir deyişle, izleyicinin medyanın sunduğu geniş yelpaze içerisinden kendi istek ve ihtiyaçları doğrultusunda seçim yapmakta olduğunu iddia etmekteydi. Bu durum şiddet içeriğinin seçilmesi ile ilgili olarak da geçerli sayılabilmektedir. Öyle görünmektedir ki, her ne kadar medyadan izlerkitleye bir içerik dayatması olduğuna dair eleştirel yaklaşımlar varlığını ve haklılığını sürdürse de, izlerkitlenin de medya metinleri içerisinde belirli içeriklere yoğun bir ilgisi bulunmaktadır. Bunların başında ise "şiddet" gelmektedir. Öyle ki suç ve şiddet içerikli programların yapıldığ1 -konusunu gerçek hayattan alan canlandırmaların yer aldığı- tematik kanallar dahi (ID Channel, TLC gibi) bulunmaktadır. Ve hatta, National Geographic, Discovery Channel vb. dünyanın en çok izlenen belgesel kanalları, suç ve şiddet içerikli programlara yayınları içerisinde yer vermektedirler. Ve bu içerik, bilindik yüzeysel şiddet gösterilerini değil; şiddetin en açı, en vahşi, en dolaysız, dahası en çekici biçimde sunulmuş halini içermektedir.

\footnotetext{
10 Kültürel Göstergeler Projesi, televizyonda yaratılan "dünya"yı, özellikle bu dünyadaki şiddetin miktarını betimlemeyi amaçlamaktaydı. Projenin nihai amacı ise televizyon dramalarını izleme ile televizyon seyircilerinin gündelik yaşamlarında "gerçeklik" kavramlaştırmaları arasındaki ilişkiyi bulgulamaktı. Proje, kurumsal çözümleme, mesaj sisteminin çözümlemesi ve yetiştirme çözümlemesi olarak üç ayrı bölümden oluşmaktaydı. Kurumsal çözümleme, televizyon mesajlarının oluşumundaki karar alma süreçlerini ve bu süreci etkileyen toplumsal aktörleri incelemeye yönelikti. Mesaj sistemi çözümlemesi ise ABD şebeke televizyonlarında (NBC, ABC, CBS) hafta sonu ve hafta içi yayınlanan dramatik program örneklerinin her yıl gözlemlenip kaydedilmesinden olușmaktaydı. Son olarak yetiștirme çözümlemesi televizyon izleyicilerinin gerçek dünyayı kavramlaștırmaları üzerinde medya aracıllğılyla oluşturulan dünyanın etkisini incelemeyi amaçlamaktaydı (Mutlu, 2004, s. 199-200). Gerbner ve arkadaşlarına göre televizyon, imgeleri ve mesajları aracilı̆̆yla toplumda var olan egemen değerleri, algıları, ortak imgeleri izleyicilerinin zihinlerine "ekmektedir" (Özkan, 2017, s. 132). Böylelikle televizyonun, gerçek dünyayı objektif bir biçimde değerlendirmekten uzak, izleyicinin gerçeklik - kurgusallık ayrımını yıkıcı, daha doğrusu egemen ideoloji savunucularının istediği yönde şekillendiren bir dünya profili ortaya çıkardığı, izleyicide de bunun yansımalarının görüldüğü sonucuna varılmıştır. Gerbner ve arkadaşlarının üzerinde uzun yıllar çalıştı̆̆ bu proje sonrasında sadece şiddet için değil, azınlıklar, toplumsal cinsiyet vb. farklı alanlar için de bir odak noktası olmuştur. Öte yandan, şiddet ve etkileri üzerine çok sayıda çalışma yapılmıştır ve yapılmaya devam edilmektedir. Bu çalışmada sadece Gerbner’in yaklaşımına değinilmesinin temel nedeni hiç şüphesiz en başından "şiddet" odaklı olarak çalışılmasıdır.

${ }^{11}$ Kullanımlar ve doyumlar yaklaşımı izleyicilerin gereksinimlerine göre iletişim araçlarını ve içeriklerini seçtiklerini ve kendi etkilerini kendileri aradığı görüşünü, kısaca "aktif izleyici" savını getirmiştir. Buna göre, insanlar basit bir şekilde davranma yerine, çevrelerine etki yapan aktif ajanlar olarak kabul edilir. Bu ajanlar etkinlikleri seçme yolları arasından amaçlarına uygun tercihler yapma gücüne sahiptirler (Erdoğan ve Alemdar, 2005, s. 162). Yaklaşım tek bir kurama dayalı olarak açıklanamamaktadır. Esasen, 1920'li yıllardan itibaren hakim olan Sihirli Mermi yaklaşımının bazı soruları cevaplamada yetersiz olduğuna yönelik bakış açısından doğan yaklaşımları kapsamaktadır. İzleyici merkezli yaklaşımlar olarak da ifade edilebilecek bu yaklaşımlar bütünü içerisinde, hiç şüphesiz "Alımlama Kuramı" da ele alınabilir. Ancak bu yaklaşım daha ziyade izleyici ve mesajın bir araya gelme durumunu anlatmaktadır ve medyada yer alan şiddetin izlerkitle tarafından nasıl okunduğuna odaklanan ardıl bir çalışmanın konusudur.
} 
Tam da bu noktada yine ID Channel'ın bir fragmanından alıntı yaparak başlamak gerekirse: "Suç ilgimizi çeker. Cinayet merakımızı uyandırır. Gizem bizi tahrik eder..." Salt bu üç cümlecik dahi esasen şiddetin medya izlerkitlesi nezdindeki yerini tanımlama çabası için yeterli bir başlangıç adımı oluşturmaktadır. İlginin çekilmesi ve merakın uyandırılması elbette bilindik söylemlerdir, ancak gizemin hiç şüphesiz şiddet ve hatta vahşet içerikli olaylara dair- bir tahrik unsuru oluşturması, pek çoklarınca şiddetin pornografik bir özelliğe sahip olduğu yönünde görüş beyan etmeleri ile sonuçlanmıştır. Gizem tahrik edicidir, çünkü çözülmesi gerekir. Gizemi oluşturan unsurlar çözülmeli, kilit noktaları bulunmalı ve teşhir edilmelidir. ID Channel ve türevi kanallarda ya da bu türden içeriklerde söz konusu olan da budur. Her ne kadar karşıt cinsler ya da hemcinsler arasındaki cinsel aktivitelerin görünür hale getirilmesi anlamında kullanılsa dahi, pornografinin ${ }^{12}$ şiddetle bağıntılı kullanımı daha ziyade, şiddetin, şiddet içerikli eylemlerin "gizeminin çözülmesine", "teşhir edilmesine” ve buna bağlı olarak da "izleyicinin bu teşhirden aldıkları zevke" -kimi zaman ise yarattığı kışkırtıcı etkiye, çoğu zaman ise izlerkitledeki suni bir infiale işaret etmektedir. Ve elbette izleyicinin bakışının odaklanmasıyla açığa çıkan ikame bir doyum duygusuna (ya da ikame doyum sonrasında kendinden duyduğu utanca veya gösterdiği ilgi dolayısıyla açı̆̆a çıkan ve olaya yansitılan bir öfkeye)...

Karen Boyle, pornografiyi tanımlamanın bakış açısıyla ilgili olduğunu ifade etmektedir. Söz gelimi feminist yaklaşım pornografiyi, bizzat kadına yönelik bir şiddet eylemi olarak tanımlamakta ve bu kavram ile olgunun medya - şiddet tartısmalarının merkezine alınması gerekliliği savı üzerinde durmaktadır (Boyle, 2005, s. 29). Ancak Boyle'un bu savı her ne kadar doğruluk payı içerse dahi, -kaldı ki farklı düzeylerde şiddeti içeren cinsel aktivitelerin açıkça gösterilmesi bağlamındaki pornografik içerik sadece kadına yönelik değildir, erkeklere, hayvanlara ve çocuklara da yöneliktir- bu şiddet sadece cinsel anlamda değildir. Baudrillard'n söylemiyle pornografik olan "görülebilirliğin, bütün şeylerin acımasız şeffafllğının müstehcenliğidir (2004, s. 134). Ve pornografik içerik, imgeler kendilerine çıplak bir bedene bakar gibi bakmamızı önerdikleri noktada açığa çıkmaktadır (Sayın, 2003, s. 12). Beden bütünlüğünün bozulması da bu bağlamda çoğu kez pornografik olarak algilanmaktadır. Söz gelimi Susan Sontag (2004, s. 70) insanların, Boston'da yayınlanan haftalık bir gazetenin sitesinde yayınlanan bir videoya olan tepkilerini aktarmaktadır. Söz konusu video Pakistan'da hazırlanmıştır ve içeriğinde 2002 yılı başlarında Karaçi’de kaçırılan Amerikalı gazeteci Daniel Pearl'ün itirafı ile hemen ardından törenle boğazının kesilmesi yer almaktadır. Siyasi anlamda bir propaganda mesajı içeren bu video, Pearl'ün yakınlarının acı çekmemesi için yayından kaldırılmasını isteyenlerle kamuoyunun olan bitenden haberdar olma hakkını savunanlar arasında ciddi bir tartışmayı beraberinde getirmiştir ancak burada belki de en önemli nokta her iki tarafın da görüntüleri "pornografik bir film" olarak tanımlayarak uzlaşıya varmış olmalarıdır. Bu örnek de göstermektedir ki pornografik olan, sadece cinsel aktivitelerin değil, büyük oranda açık, aleni, şok edici, kimi zaman tiksindirici olmakla birlikte merak uyandırıcı ve bu doğrultuda dikkat çekici ve kendini izlettirici diğer eylemlerin gösterimini de işaret etmektedir.

Siddet 21. yü̈sylda kitle iletişim aragllarna taşınarak daha büyük kitlelere seyirlik hale gelmiștir. Her gün televisyonlarda cinayet, aile içi siddet, kadina ya da cocuğa yönelike siddet, töre cinayeti, kan davalar, intihar, namus cinayeti gibi sayısız siddet haberleri iəlenebilmektedir. Üstelik. bu tür șiddet olaylarna haberler dişında diə̌ilerde, kadin programlarnda batta çizgi filmlerde bile rastlanabilmektedir. Artık günümüzde kitle iletisim

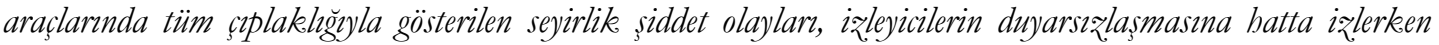
zevk almasina neden olmaktadir. Susan Sontag tarafindan "Pornografik Șiddet" ya da "Șiddetin Pornografisi" olarak tanmmlanan bu durum birçok iəleyici araștrmasina konu olmustur. Bu durumda pornografik şiddet, medyada yer alan her türlü şiddet olaylarm kapsamaktadır (Akıner, 2014, 2).

Şiddetin pornografik bir biçimde sunulması ya da pornografik bir işleve sahip olması,-her ne kadar her zaman amaç tam olarak bu olmasa da- esasen yeni bir olgu değildir. Şiddet ve onun pornografik sunumu, antik zamanların en gelişmiş uygarlıklarında dahi yer almaktaydı. Üstelik bu var olma durumu Girard'a göre; sadece bir ceza, denetim, bir düzenleme sistemi ya da tanrılar için sakinleştirmenin bir aracı olarak değil, aynı zamanda bir zevk nesnesi olarak da kendini göstermektedir. Ve bu durum bir hayli yaygındır. Öyle ki Benjamin, "Aynı zamanda bir barbarlık belgesi olmayan, hiçbir uygarlık belgesi yoktur"

12 Pek çok kaynakta "pornografi” kelimesinin Antik Yunanca kökenli olduğu belirtilmektedir. Yunancada "pornographos" kavramı, porne (hayat kadını) ve graphien (yazmak) kelimelerinin bütünleşmesinden oluşmakta ve "hayat kadınları hakkında yazmak/çizmek" anlamına gelmektedir. Kavram İngilizceye 19. Yüzyılda geçmiştir (http:// oxforddictionaries.com; Erişim Tarihi: 2018). Antik çağlarda, duvar resimlerinde veya benzer görsellerde çıplak erkek ve kadın figürlerin cinsel ilişkileri resmedilmekteydi. Mevcut terminolojideki pornografi, cinsel heyecanı uyarmak için cinsel organları veya aktiviteyi açıkça gösteren materyaller olarak tanımlanabilmektedir. Bu noktada örneğin bir anatomi kitabı, pornografik değildir. Anahtar terim bu anlamda, cinsel heyecan uyandırmaktır (Sargın, 2007). 
demiştir (2007, s. 256). Binlerce ylllık süreç içerisinde değişim şüphesiz yaşanmıştır. Uygarlıklar kurulmuş ve y1kılmıs, hukuk ve adalet sistemleri sürekli ve yeniden şekillenerek şiddet içeren toplumsal ve kültürel uygulamalar yeniden yapılandırılmış (kan davası ya da namus cinayetlerine karşılık ülkemizde çıkan yasalar bu duruma örnek gösterilebilir), insanlar toplumsal statüleri fark etmeksizin bedensel bütünlüğüne sayg1 duyulması gereken varlıklar olarak kabul görmeye başlamışlardır (örneğin bu nedenle kölelik sistemi ortadan kalkmıştır). En azından görüntü bu yöndedir; ya da olması gereken olarak kabul gören durum budur. Bununla birlikte, insan türünün kendi cinsine karşı şiddete, daha doğru bir ifadeyle bu şiddete tanık olmaya yönelik ilgisi azalmamış görünmektedir. Bugün medyada farklı biçimlerde karşımıza çıkan şiddet içeriklerine olan ilgi bunun önemli bir göstergesi olarak kabul edilebilir niteliktedir. Ancak bu kısma gelmeden önce şiddetin pornografisini tarihsel geçmişi üzerinden biraz daha tartışmakta yarar görünmektedir.

Freud'un da ifade ettiği üzere ilkeller bizim çağdaşımızdır. Ve bizler, gündelik hayat, sanat, efsaneler ve mitler gibi gelişim sürecimizi gösteren izler taşıyan evrimsel aşamalarımızda, tarih öncesi atalarımızla benzerlikler paylaşmaktayız (Freud, 2012, s. 3). Belki bu izler bugünün insan türü için gözle görünür değildir. Ancak çağdaşlarımızın izleri, korkularımız, tutkularımız ve bilişsel yeteneklerimiz gibi daha içgüdüsel olanda ya da iç dünyada kendini göstermektedir. Jung bu durumu, özellikle arketipler kavramıyla, ortak ya da kolektif bilinçdışı olarak açıklamaktadır. Jung'a göre arketipler, gördüklerimizi ve gerçekleştirdiğimiz şeyleri düzenleyen ilkelerin rolünü oynamaktadır. Birçok arketip arasında, hangi ırktan, kültürden, dinden ve / veya toplumsal gruptan olduğu fark etmeksizin, "ölüm ve cinsellik" insanllğın kolektif bilinçaltıdır (Jung, 2001, s. 152). Bu nedenle, ölüm ve cinsellikle ilgili imgeler insan türü üzerinde bir etkiye sahiptir. Bu etki geçmişten bugüne ölümü ve cinselliği, herhangi bir şüpheye yer birakmaksızın, seyirlik olaylara indirgemektedir. Bugün, reklamlardan dizilere, filmlerden spor karşlaşmalarına, dijital oyunlara vb. her türden görselde (ve hatta yazılı anlatılarda), ölüm (ya da korku) ve cinselliğin bir biçimde tezahür ettiği görülmektedir. Bu tezahürlerin çoğu da eğlence sektöründe, özellikle de kitlesel eğlencede ortaya çıkmaktadır. Bu noktada, atalarımızın da (Freud'un söylemiyle çağdaşlarımız) bu unsurlara kendi gündelik hayatlarında yer verdikleri görülmekteydi. Özellikle de söz konusu şiddet olduğunda. (Erdem, 2014, s. 284).

İnsanın kendi türüne yönelik uyguladığı şiddetin deyim yerindeyse teşhir edilmesi insanlık tarihinin başlangıcına değin götürülebilmektedir. Semavi dinlerin kitaplarınca Kabil'in kardeși Habil’i öldürmesine kadar giden ve peşi sıra aktarılan şiddet içerikli olayların anlatılması, Hıristiyanlıkta Hz. İsa'ya çektirilen acıların gerek kutsal metinlerde, gerek kutsal mekanlarda yer alan görsellerde ve hatta sanat eserlerinde tüm açıklğ̆ıla yer alması bu duruma örnek olarak gösterilebilir. Dini içeriğe sahip bu aktarımlar genel itibarıyla Yaradan tarafindan oluşturulmuş kurallara uyulmasını sağlama ve doğru yolu gösterme amaçlı dersler niteliğini taşımaktadır. Bunlar haricinde oluşturulan imgeler ve / veya anlatılar ise biraz daha farklı niteliğe sahiptir ve aleni bir biçimde uygulanan / maruz kalınan şiddetin teşhirini içermektedir. Bu bağlamda beden bütünlüğünün insan eliyle bozulmasının ve bu bozulmanın teşhir edilmesinin en önemli örneklerinden biri, belki de başlıcası gladyatör dövüşleridir ${ }^{13}$. Fromm bu dövüşleri, "güçsüz insanların şiddetten sadistçe zevk almaları" olarak nitelendirmektedir (Fromm, 1979, s. 29'dan akt. Türkoğlu, 2007, s. 231). Ansiklopedik bilgilere göre gladyatör oyunları başlangıçta kutsal ruhlara insan kurban etmek amacıyla düzenlenen törenlerdir. Roma'da ilk kez İ.Ö. 264 yllında başlamış ve İ.S. 404 yllında Hıristiyanlığın İmparatorluktaki egemenliği sonucu yasaklanmasına dek büyük ilgi görerek sürdürülmüştür (Türkoğlu, 2007, 232). Esasen bugün, oyuncuların bazen birbirini ciddi bir biçimde yaralamaları ile sonuçlanan bazı spor dalları bu noktada gladyatör dövüşlerinin daha medeni hali olarak da görülebilir. Olimpiyatlarda da karşımıza çıan boks, kick boks başta olmak üzere tüm dövüş sporları bu duruma örnek gösterilebilmektedir. Antik Yunan medeniyetinde de benzer uygulamaların olduğu ve günümüze yansıdığı bilinmektedir. Bugün, herhangi bir kural olmadığı halde bütünüyle eğlence amaçlı sergilenen Amerikan Güreşi, pankreas, kafes dövüşleri gibi performanslar, Antik Yunan'dan bize miras kalmış kanlı dövüşlerin yansımalarıdır. Antik dönemlerdeki bu uygulamalar her ne kadar Kilise tarafindan baskılanmaya çalısıllmış ve dışlanmışsa da yerini farklı seyirlik

\footnotetext{
${ }^{13}$ Hiç şüphesiz gladyatör dövüşleri, şiddetin pornografisi bağlamında ele alınabilecek her türden söylemi destekler niteliktedir. Bu noktada, söz konusu etkinlikler detaylıca incelenmesi gereken unsurlardır ancak, çalışmanın bütünlügünü bozmamak adına bu çalışmada kısaca yer verilmekte, daha detaylı incelemeler için okuyuculara kaynak önerisinde bulunulması uygun görünmektedir. Galdyatör dövüşleri için Nurçay Türkoğlu'nun (2007), İletişim Bilimlerinden Kültürel Callşmalara Toplumsal İletişsim isimli kitabında "Seyirlike Ölïmler" başlıklı bölüme; Stephan Wisdom ve Angus McBride’ın (2001) Gladiators 100 BC - AD 200 isimli kitaplarına; Thomas Wiedemann'in (2002) Emperors and Gladiators isimli kitabına bakılabilir. Bu konu hakkında Abdurrahman Uzunaslan'in (2005) Antik Roma'da Gladyatör Oyunlar başlıklı makalesi de önemli kaynaklardan biri olarak göze çarpmaktadır. Söz konusu kaynaklara dayalı detaylı bilgi bu çalısmanın kaynakça bölümünde yer almaktadır.
} 
ölümcül gösteriler almıştır. Örneğin şövalye turnuvaları, kan için söz konusu olan açlığın örnekleri olarak Kilise tarafından hoş karşılanmamış, bununla birlikte bu gösterileri engellemek için bir önlem de alınmamıştır. Orta Çağ Avrupasi'nda bu eğlenceleri seleflerinden ayıran önemli özelliklerden biri ise şövalye turnuvalarının soyluların katılımı ile gerçekleşmesidir (Bloch, 1983, s. 380). Hiç şüphesiz tarihin sayfaları arasından bu ve benzeri türde çok daha fazla örnek çıkarılabilir. Bununla birlikte asıl olan gerçek ya da kurgusal bu türden gösterilerin şiddeti seyirlik bir nesne, bir haz nesnesi haline getirmesidir. Şiddet geçmişte olduğu gibi bugün de seyirlik hale getirilmekte, deyim yerindeyse eğlence amaçlı kullanılmaktadır. Dahası, medya içeriğinin dolayımlanmasının kitlesellik düzeyi arttıkça ya da internet gibi denetimi zor bir alanın yaygınlık kazanması söz konusu oldukça, şiddet içerikli imgeler daha da görünür hale gelmektedir.

Öte yandan öyle görünmektedir ki, medyada yer alan şiddet içeriğinin artmasının yanı sıra insanların bu içeriğge olan meyli de gün geçtikçe artmaktadır. "Anlaşılan o ki, acı çeken bedenleri gösteren resimlere karşı duyulan iştahlı merak, neredeyse çıplak bedenlere gösterilen arzulu merak kadar şiddetlidir" (Sontag, 2004, s. 40). Daha önce de ifade edildiği üzere, şiddet ile birey arasındaki ilişki bütünüyle ikiyüzlü ve marazi bir ilişkidir. İkiyüzlüdür zira, birey -özellikle de izleyici olarak konumlandırıldığında- bir yandan şiddet içeriğine karşı çoğu zaman eleştirel bakmakta, şiddet uygulayanı ise toplumdan dışlanması gereken varlık olarak tanımlamakta; öte yandan şiddet içeriğine yoğun bir merak ve ilgi duymaktadır. İzleyicinin bu ilgisi çoğunlukla eyleme dönüşmemektedir. Diğer bir deyişle, şiddet içeriğine maruz kalan çoğu birey şiddet uygulayıcısı haline dönüşmez. Ancak, içeriğin şu ya da bu şekilde, kendisinde yarattığı ikame doyum duygusuna da karşı koyamamaktadır. Esasen bu türden bir içeriğe olan ilgisinin nedeni de budur ${ }^{14}$. Açıktır ki, beden bütünlügünün bozulması, izlerkitle tarafindan çoğu kez pornografik olarak algılanmakta ve yorumlanmaktadır. Hatta çoğu zaman cinsel eylemlerin pornografik olarak adlandırılmalarından çok daha fazla bir biçimde...

Ölümden söz edildig̈inde insanlar gülmektedirler. Bu sinirli ve müstehcen bir gülüstür. Cinsellikten söz etmekse artık bu türden bir tepkige bile neden olmamaktadı; çünkü cinsellik yasallașınca, ölüm pornografik bir görünüme sabip olmuștur. Cinselliği "öggürlestiven" toplum, ondan boşalan asal bir gį̧li ritüel ve yasak. ișlevinin eksikliğini ölümle gidermeye çalssmaktadrr. Daba önce yasanmıs dini bir evrede ölïm gizlenmeyen, herkese açı, berkesin önünde olup biten bir șeyken cinsellik yasake bir șeydi. Günümüzdeyse durum tersine dönmüsstür (Baudrillard, 2001, s. 335).

\section{Medyada Şiddetin Estetize Edilmesi}

Estetik, kavramsal olarak ve kapsam açısından antik çağlardan bugüne üzerinde en çok tartışlan alanlardan biri olagelmiştir. Zira estetik hayli göreceli bir kavram olan güzelliği konu edinmekte ve bu bağlamda bilimsel bir altyapı oluşturmaya çalışmaktadır. Bu çalışmada da, güzellik ve estetiğin, -daha doğru bir ifadeyle estetik algı ve yargının- öznelliği göz ardı edilmeden medyada yer alan şiddet içeriğinin nasıl estetize edildiği konusuna odaklanılmaktadır. Bu bağlamda, ilk olarak estetiğin tanımına ve kısaca gelişimine değinmek uygun görünmektedir.

Estetik, güzelliğin felsefesi olarak tanımlanabilecek bir kavramdır ve bilinen bir gerçekliktir ki "güzellik nedir?" sorusunun cevabı, oldukça tartsşmalı bir alanı karşımıza çıarmaktadır. "Gǚelliği neyin

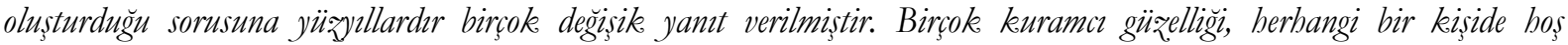
deneyimler uyandiran nesnenin özelliği olarak ifade etmiştir. Nesne temelli bu yaklassımda güzellik nesnenin firiksel niteliğine bağh bir kavram olarak ele alnmısttr. Birçok kuramcida güzelliğin bakan kişinin gözzünde olustuğunu; bir şeyin duyulara hoş geldiüzi sürece güzel olabileceğini savunmustur. Özne temelli bu yaklaşımda güzellik kişinin kendine özgü özelliklerinin bir işlevi olarak tammlanmıştr" (Tekel, 2015, s. 150). Her ne kadar bilimsel temelleri 18. Yüzyılda atılsa da estetik, düşünsel boyutuyla illk olarak Antik Yunan'da ele alınmıştır.

Düsünce taribinde estetik alanla ilgili problemleri bağzmsı bir disiplin balinde olmasa da felsefi biçimde ille olarak ele alp inceleyen filozof Platon'dur. Platon, estetig̈in konusu olan güzeli, felsefi bilginin konusu olan doğru ve ablaki bilginin konusu olan iyi ile birlikete ele alp incelemişstir. Bununla birlikete, Platon'dan önce de birçok filozof, felsefi bir biçimde olmasa da güzelle ilgili düsüncelerini ortaya koymuştur. Örneğin, Platon'dan önce Pythgoros güzelliği, birbirine zıt olan șeylerin, karşıtllklarn harmanlanmasyla ortaya çlkan dengeden olusan uyum olarak. ifade ederken; Herakleitos güzeli, uyum, ahenk ve armoni olarak tammlamlarken;

\footnotetext{
${ }^{14}$ Elbette bu türden bir çıkarım yapmak, ancak ve ancak izlerkitle üzerinde geniş kapsamlı bir araştırma ile mümkündür. Bununla birlikte, özellikle Kullanımlar ve Doyumlar yaklaşımı gibi izleyiciyi merkez alan teorik bir alt yapı ile ortaya konan çalıșmalarda, izlerkitlenin seçim yapma özgürlüğü, daha da önemlisi seçimleri, metin içerisinde açılanmaya çalışılan şiddet ve birey ilişkisinin neden ikiyüzlü ve marazi olduğu savını destekler niteliktedir. Yanı sıra bu savla ilgili örnekler, çalışmanın Sonuc Yerine başlı̆̆ı altında tartışılmaktadır.
} 
Sokrates ise güzeli iyi olanla ayn şey olarak, görüyordu. Bu nedenle Sokrates ablaki değerlerle estetik değerleri birbirlerine yaklastrmakta hatta aymlasturmaktader (Șimsek, 2014, s. 332).

Estetik, Grekçe 'aisthesis' (duyum, duyulur alg1) ya da 'aisthanesthai' (duyu ile alg1lamak) sözlerinden gelmektedir. Ayr1 bir felsefi disiplin olarak estetik ve "estetik" terimi, ilk kez Alexander Gottlieb Baumgarten tarafindan kullanılmıştır. Yeni disiplinin tanımını 'duyusal bilginin bilimi' olarak yapan Baumgarten, estetiğin alanını sadece güzel sanatlarla sınırlı kalmayacak biçimde genişletmiştir (Ertürk, 2016, s. 119). 1750-1758 yılları arasında yayımlamış olduğu 'Aesthetica' adlı eserinde bu bilimi temellendirip, estetiğin konusunu belirleyerek sınırlarını çizmiş; estetiği, özgür sanatlar teorisi, aşağı bilgi teorisi, güzel üzerine düşünme ve duyusal bilginin bilimi olarak tanımlamıştır (Şimşek, 2014, s. 332). Ve bu noktada ele alınabilecek şu söylemi de önemlidir: "Güzellik, gerçekliğin tanımlanmasına olanak sağlamıştır" (Gottfried Herder, 2006, s. 187). Baumgarten ve O'nun temelini oluşturduğu düşünsel zeminden ilerleyenlerin estetiğin kapsamını genişletme çabalarına rağmen, kavram sıklıkla güzel sanatlar ile birlikte anilmaktadır.

Bir sanat çalş̧ması estetike özellikler ve etkilere sahiptir ve (veya) bunun için tasarlantr. Bu çerçevede estetik, aslinda, onu gösteren niteliklerin çoğu kez betimlenmiş olmasina karşıın, 'sanat' ve 'yaratıc sanatın' özellessen çăgdas genellenmesiyle doğrudan doğruya ayn çizgide hareket eden ve 18. yüzynlin sonundan itibaren böyle anlaşılmaya başlanan bir terimdir (Williams, 1993, s. 121).

Öte yandan süreç içerisinde, güzelliğin bakan kişinin gözünde oluştuğu düşüncesi hâkim olmuştur. 17.yüzyll İngiliz düşünürü Locke, güzelliğin hem öznel hem de nesnel niteliklere sahip olduğu görüşünü savunan ilk kişi olmuştur. Kant da güzellikte nesnel ve öznel düşünce ayırıma dikkat çekmiştir. 20.yüzyıl modernist düşünce ekolünde estetik 'hazsal' bir değer olarak ifade edilmiş, post-modern düşünce ekolünde ise modernizmin önerdiği özne merkezciliğin tersine 'nesne' ön plana çıkmıştır. Özne ve nesne temelli yaklaşımlar estetik yargının doğasına da 1şık tutmuştur (Tekel, 2015, s. 150).

Bu noktada ele alınması gereken temel konulardan biri de estetik yargının nasıl oluştuğudur. Öznel ya da nesnel, hangi yaklaşım göz önünde tutulursa tutulsun, estetik yargının oluşumu belirli duyusal ve bilişsel süreçlere tabiidir. Leder, vd. (2004), A Model of Aesthetic Appreciation and Aesthetic Judgments isimli çalışmalarında, estetik beğeni ve yargıların nasıl ortaya çıktı̆ını tartışmaktadırlar. Buna göre estetik yargılama ve sonucunda beğeninin oluşumuna dair süreç, estetik ilginin odaklandığı bir nesnenin varlığı ve bu nesneye karşı bireyde duygusal bir durumun açığa çıkması ile başlamaktadır. Birey öncelikle algısal bir analiz gerçekleştirir ve bu analiz esnasında zihinsel olarak sırasıyla karmaşa, zıtlık, simetri, sıralama ve gruplama gibi işlemleri gerçekleştirmektedir. Ardından önceki deneyimlerinin de etkili olduğu örtülü bilgi entegrasyonu süreci gelmektedir. Bu aşamada bireyin gerçekleştirdiği bilişsel işlem esasen, karşılaştı̆̆ nesneye dair algıladıklarını önceki deneyimlerinin oluşturduğu bir süzgeçten geçirmektir. Böylelikle bir kavramsallaştırma edimini de gerçekleştirmiş olmaktadır. Bir sonraki aşamada, hem geçmiş deneyimleri hem de alana özgü uzmanlı̆̆, bilgisi, ilgi düzeyi ve kişisel zevklerinin de söz konusu olduğu bir düzeyle etkileşime geçmekte ve tarz ile içeriği içsel bağlamda sınıflandırmaktadır. Bu etkileşim düzeyleri, bireyin bilişsel hakimiyetine de etkide bulunmakta ve bir sonraki aşamada özgün bir sanat yorumu ile kendi kattı̆̆1 yorumu birleştirmektedir. Son aşamada, bilişsel durum, idrak ve eserin yarattığı belirsizlik duygusu etkileyici durum ve tatmin ile birleşmekte ve birey nesne üzerinde bir değerlendirmeye gitmektedir. Böylelikle, nesneye dair bilişsel hakimiyet aşamasında gerçekleşen değerlendirme sonucunda estetik yarg1, etkileyen unsur ve tatmin düzeyi bağlamında da bir estetik duygu ortaya çıkmaktadır. Bu durum bütünüyle bireyin estetik (ya da estetik olmayan) bir nesneye dair yargılama ve duygu edinimi sürecini yansitmaktadır.

Estetik deneyim ve sonucunda ortaya çıkan estetik yarg1 hayli öznel bir durum olarak açığa çıkmaktadır. Öte yandan literatürde çoğu zaman nesneye dair özellikler üzerinde durulmaktadır. Xenakis ve Arnellos (2014, s. 5), literatürde çoğu kez estetik nesnelerin çoğu zaman 'belirli bir işlevi taşıyan' tüm şeyler olarak kabul edildiğini vurgulamaktadırlar: ki bu da "estetik bir ilgi ya da deneyim uyandran bilgiyi iletmek. için estetik bir tepki biçimini keşkertmak"tır. Bununla birlikte, bu tanımda belirsiz bir varsayım olduğunu da eklemektedirler. Zira onlara göre, nesnenin deneyimde öznel olarak değerlendirildiği kabul edilmesine rağmen, yazarlar bir şekilde alg1 içinde bir tür 'objektiflik' olduğuna inanmaktadırlar. Bu perspektiften nesne, özellikleriyle ve estetik biçimleriyle açı bir şekilde ilişkilendirilebilen bazı algısal özellikleri olan özel bir şeyi taşımaktadır. Bu bakımdan estetik algı, formaliteyi estetik bir özellik ile ilişkilendiren "doğru algılamaya" dayanmaktadır. Doğruluk ve estetik özellikler olumlu veya olumsuz değerlere sahip olabilmektedir. Algilar, estetik olmayan özelliklerin "uygun" bir organizasyonuyla belirlenebilmekte, ancak onlara indirgenememektedir. Bu bağlamda Kim (2006, s. 17), özellikle Bauhaus okulundan beri 
"nesnelerde estetiğin” uygulanmasının, tasarımcılar ve sanatçılara, onların doğruluk hislerini estetik özelliklerine resmetme konusunda rehberlik eden, sabit normlar ya da sağlam prensiplerle ilgili olduğunu ifade etmektedir. Tunalı da (1998, s. 90) her estetik objenin bir görünüş olduğunu, duyarlllı̆̆a dayandığ için de bireyde estetik bir etkilenme oluşturduğunu ve bireyin bunu haz ve hoşlanma olarak yaşadığını vurgulamaktadır. Sadece yaşamakla kalmamakta, aynı zamanda onu bir değer ile dile getirerek "güzel" kavramı ile nitelendirmektedir.

Bu noktada karşımıza “estetik değer” kavramı çıkmaktadır. Kant, estetik değeri karakterize eden unsurlar1 şöyle sıralamaktadır (Buda, 2017, s. 49):

- Bir nesneden alınan tat, herhangi bir çıkardan bağımsız olarak ortaya çıkan zevk veya rahatsızlık ile ilgili olarak bir nesneyi veya bir temsili yargılamaktır.

- Nesne, evrensel olarak herhangi bir kavramsallaştırma çabası olmaksızın beğeniliyorsa güzeldir.

- Güzellik bir nesnenin nihai halinin şeklidir çünkü bir nesnenin temsili olmadan bu nesnede alg1lanır.

- Sağlaması gereken tatminin bir nesnesi olarak, herhangi bir kavrama ihtiyaç duymadan kabul edilen nesne güzeldir.

Kant'a göre bu noktada, estetik değerin bizzat nesnenin özelliklerinden kaynaklanan tatmin duygusunda yattığını vurgulamaktadır. Bu duygu, nesne ile karşılaşan bireyde duygusal bir tatmin yaratmaktadır ve bu tatmin herhangi bir kavramsallaştırmaya ihtiyaç duymadan birey tarafindan kabullenilmektedir. Bu, estetik değerin evrensel geçerliliğidir (Buda, 2017, s. 46).

Hartmann'da ise estetik değerin en temel argümanı şudur: “Zarif, duygusal, büyüleyici, komik, trajik ve diğerleri gibi diğer estetik niteliklerin yanı sıra, yüce olan (güzelliğin zenginleştirilmiş uzantısı) vardır”. Zira, güzellik sadece onu yaratan ya da tasarlayan için değil, bunun üzerine düşünen insan için de vardır (Buda, 2017, s. 47).

Tunalı (1998, s. 78) estetik değer konusunu "Bir doğa parçası, bir sanat yapıtı ne zaman bir estetik değer varlığı olarak kavranabilir?” sorusuyla ele almakta ve buna şöyle cevap vermektedir:

"Buna, eğer onlar estetik bir algulamanın objesi olurlarsa diye karşllk verebiliriz: O balde estetik obje, bir estetik obje olabilmek için, insandan özel bir etkinlik, özel bir kavrama etkinliği bekler. Nedir bu özel kavrama etkinliği? Öyle özel bir kavrama etkinliği ki, bu kavrama etkinliği ile bir estetike obje, doğal bir objeden ayrlir ve estetik bir obje olarak belirlenir. Böyle bir kavrama etkinliği, ancak sübjektif nitelikler ile belirlenebilir. Sanat (ifadesinin) ve estetik duyarlğ̆ın objesi daima 'insan için var olma'yn içine alır. Ama, bir objenin bir süje için var olması yeterli değildir; bir süjenin de bir obje için bir süje olması gerekir: Estetik objeyi, gerçek bir estetik hazzın objesi yapmak için. Obje, süjeye gereksinme duyar, tıpki (yüzyllik bir uykudan uyanabilmesi için masal prensesi) Dornröschen'in kendisini uyandıracak prensin öpücügüne gereksinme duymasi gibi. O halde süje, nasıl bir tavır ile estetik obje'ye eğilmelidir? Bu eğilme, bütün klasike estetiklerin anlayısına göre, sübjektif bir tavir alma ile olacaktur. Marxizm de bu anlayısa katılir. Bu sübjektiflik (öznellik), daha önce işaret etmis olduğumuz gibi, duyusalliğa dayalidır. Süje, estetik objeyi salt duyusal bir obje olarak kavramalıdır. Sanatç anlatımınm ve estetik duyarliğın obje'si, birçok belirleme ve ilgilerin zengin bir tümlüğ̈̈nü gösterir. Burada söz konusu olan bu çokluğun birliği, duyusal-somut olmaktan başka bir şey değildir. Daha en bastan bu, sunu disarda birakır: Soyutlamalar, kavramlar, yasalar, vb. sanatç anlatımınn ve estetik duyarlĭğn özel bir biçimi olamazlar. Buna göre, estetik obje, duyusal-somut bir obje olup, süje, böyle bir tavirla estetike objeye yöneldiğinde onu estetik olarak kavrayabilir."

Estetik değerin ortaya çıkışı, bir estetik objenin varlığına ve bu obje karşısındaki duygularının varlığına bağlıdır. Elbette estetik tarihi boyunca bu iki unsur tartışılagelmiştir ${ }^{15}$. Örneğin;

Berlyne (1974) estetik yargmm nesnenin algisal niteliklerine bağh bir reaksiyon olduğunu ve bu reaksiyonun nesnenin fiziksel özelliklerine (elemanlarm bir araya geliş kalitesine) dayandiğın belirtmiștir. L. Wittgenstein (1958) gibi pek çok kuramo estetik yargilarn temellindeki duygusalliğ kaldırarak, onun yerine bilgiyi koymus estetik yarginin olusumunu nesnenin özellikleri ile sinurl tutmustur. Bu zamana kadar yapılan pek çok calismada da nesnede var olan denge ve orantımn (Birkhoff, 1933; Arnheim, 1974; Gombrich, 1995; Höge, 1995; Locher, 2003) estetik yargzy pozitif etkilediüi ortaya konmustur. Birçok çalıșma da nesnenin simetrik ya

\footnotetext{
$15 \mathrm{Bu}$ çerçevede, sadece estetik değer konusu ve kapsamı ile ilgili yapılan çalışmaları ele almak dahi başlı başına bir çalışma yapılmasını gerekli kılmaktadır. Bu çalıșmada ise bağlamdan kopmamak adına özet olarak sunulmaktadır. Konu ile ilgili daha kapsamlı bir bakış için İsmail Tunalı’nın (1998) Estetik isimli kitabına ve ayrıca Ayşe Tekel'in (2015) makalesine bakılabilir.
} 
da asimetrik olmasimn (Berlyne, 1971; Jacobsen and Höfel, 2002), karmasslkllk veya basit olmasmmn (Moshagena ve Thielschc, 2013) benzer ya da farkh olmasmm (Berlyne, 1970, 1971; Hekkert ve van Wieringen, 1990; Hekkert ve diggerleri, 2003; Solso, 2003) estetik, yargyy etkilediği saptanmustrr. Birkhoff (1933) ve Eysenck (1941), bir nesnenin estetig̈inin sadelik ve karmaşıklk olmak üzere iki faktöre dayandiğm belirtmişler ancak bu faktörler arasindaki iliski konusunda uzlasmaya varmamışlardir. Nesnedeki sadelik ya da süslemenin ölçüsü ile ilgili Hekkert (2003) insanlarn etkinin büyüklï̈̈ü konusunda wzlasttklarn sürece, sonucun estetik çekiciliği konusunda anlaşacaklarm belirtmiştir. Berlyne (1974) orta uyarlma potansiyeli olan nesnelerin, algilayan kişide maksimum tatmin edici etkiyi yarattğm, çok düsük veya çok yüksek uyarma potansiyeli olan nesnelerin ise hos algilanmadiklarm belirtmistir. Nasar'da (1994) benzer șekilde nesnede var olan ilmom uyarma potansiyelinin pozitif estetik deneyim üreteceğini vurgulamıştır (Tekel, 2015, s. 153).

Öte yandan;

Güreli tanmlamada özne temelli yaklasımlar 19. yy.'da ağrrlk kazanmıs, bu yüryzlda Croussaz, Du Bos, Hutchosen, Burke, Lipps, Worringer, Jouffroy, Spencer, Alison, Hume, Schopenhover, Taine, Guyan, Lalo, Marks ve Lukacs gibi filozoflar güzel kavramm bireye ve topluma bağg güzellike algz ve yargisı ile tartșmaya başlamıştrr. Bu dönemde Kant, Schiller, Hegel ve Vischer önderlig̈inde kurulan yeniçă̆ düș̈̈nce sistemi ile de güzellik özne nesne arasindaki ilişki bağlamında değerlendirilmeye başlanmuştır (Tekel, 2015, s. 154).

Şimdiye değin aktarılanlar ş̧ığında denilebilir ki, bir nesne, öznede "haz" duygusunu ortaya çıkardığında estetikten söz edilebilmektedir. Nesnenin özellikleri elbette önemlidir ve estetik bilimi açısından bakıldığında pek çok kriter, estetik yargiyı etkilemektedir. Bununla birlikte, nesnenin öznede yarattığ1 duyusal ve duygusal haz, özellikle şiddetin estetizasyonu söz konusu olduğunda büyük önem taşımaktadır. "Şiddet" unsurunu barındıran sanat eserleri de bu bağlamda tartışlabilir.

Esasen şiddet, sanatın hemen her alanında var olagelmiştir. Resimde, müzikte, heykelde, tiyatroda ve daha nicelerinde, bir aktarım ve / veya dışavurum unsuru olarak yer aldığı gerçekliğinden hareketle şiddetin bu alanları beslediği savı da ileri sürülebilmektedir. Goya, Picasso, Courbet, Caravaggio, Frida Kahlo gibi pek çok ressam şiddetle ilgili olarak kendi yaşamlarından anekdotları, hayal dünyalarını ya da dünya ve içinde yaşadıkları toplumsal olayları, tuvale yansıtarak muazzam sanat eserleri ortaya koymuşlardır. Müzik alanında, özellikle rock, rap ve heavy metal gibi spesifik alanlarda şiddet sıklıkla işlenen bir öğedir. Bu tür müziklerde, şiddet bizzat melodinin içerisinde yer aldığ kadar sözlerde de bulunmakta, sıklıkla da şarkılar için çekilen video kliplerde kullanılmaktadır. Öte yandan klasik müzik eserleri de şiddetle bağlantılı kullanılmaktadır. Örneğin Otomatik Portakal filminde, Beethoven'nn ezgileri, filmdeki şiddeti vurgulayıc1 bir nitelik taşımaktadır. Keza, yamyam bir seri katilin hikayesinin anlatıldığı Hannibal filminin ana karakteri, cinayetlerini klasik müzik eşliğinde işlemektedir. Kimi zaman ise klasik müzik tüm naifliğine karşın en şiddetli duyguları da -Vivaldi’nin Dört Mevsim’inin Kış kısmı gibi- açı̆̆a çıkarabilmektedir. Bu noktada verilebilecek örnek sayısı elbette ki artırılabilir.

Bununla birlikte, şiddetin estetize edilmiş formunun en çok karşımıza çıktığı alan medyadır. Medyanın her bir türünde ve bu her türden medya için üretilmiş olan pek çok içerikte şiddet ve onun duyulara hoş gelen, hiç değilse haz yaratan etkisi görülmekte ve hissedilmektedir. İ.Ö. 200'lü yıllarda arenada olup bitenleri izleyen insan topluluklarının coşkusu bugün ekran karşısındaki bireyde tezahür etmektedir. Tekrar Girard'ın bu konudaki söylemini hatırlamak gerekirse; şiddet yüzyıllar hatta bin yıllar öncesinin en gelişmiş medeniyetlerinde bile bulunmaktaydı. Sadece bir ceza, denetim, bir düzenleme sistemi ya da tanrılar için sakinleştirmenin bir aracı olarak değil, aynı zamanda bir haz nesnesi olarak. Bu noktada Girard (2003, s. 369) "farmakon 16" ve "katarsis" kavramlarına ve aralarındaki benzerliğe vurgu yapmaktadır. "Şiddet ve Kutsal" adlı kitabında Girard, şiddete dayalı gösterilerin, ritüellerin ve benzer uygulamaların antik toplumlarda şiddeti gidermek için kullanıldığını anlatmaktadır. Bu tür uygulamalarda baskın olan rahatlama duygusudur. $\mathrm{Bu}$ duygunun baskınlı̆̆1 ise farmakon ve katarsis kavramlarının birlikteliğini ortaya çıkarmaktadır. Günümüz dünyasında da birey, atalarının izinden gitmektedir. Medya içeriğindeki şiddeti, bir tür sağaltma aracı olarak kullanmaktadır. Çoğu kez farkında olmamakla birlikte birey, -ki burada yine Freudyen bir bakış açısı söz konusudur- içgüdüsel olarak bir ikame doyum arayışındadır. Ancak bu şiddet

\footnotetext{
16 Farmakon Antik Yunan'da hem zehir hem de panzehir anlamında kullanılan bir kavramdır. Platon dahil pek çok filozofun söylemlerinde rastlanılmaktadır (https://flutuante.wordpress.com/2009/08/01/pharmakon-the-cure-or-the-poison/; Erişim Tarihi: 10.09.2018). Girard (2003, s. 369) ise bu çift anlamlıllğı, şiddet içerikli tören ve ritüellerin, toplumdaki şiddeti baskılamadaki rolünü açıklamak üzere kullanmaktadır.
} 
belli ölçülerde olmalı, parmakları gündelik hayata dokunmamalıdır. Bu nedenle de şiddet fantazmagorik ortamlarda aranmaktadir ${ }^{17}$.

Öte yandan, bireyin bu arayışının farkında olan medya sunduğu içeriklerle bu durumu teşvik etmektedir. İster Girard'ın da vurguladığı üzere bir tedavi yöntemi, ister izlenme oranlarını artırıcı bir faktör, isterse farklı kişi ve kurumların bir iktidar sembolü... İzleyici aradığı şiddeti bulmalı, bu şiddetle de ikame bir doyumu yaşamalıdır. Ancak, bireyin gerçek şiddetin vahşi ve çirkin yüzünü görmekten kaçınması, şiddete karşı duyduğu açlığın önünde ciddi bir engeldir. $O$ halde şiddet estetize ederek sunulmalıdır. Gerçeklik ve kurgu ayrımının yapılabildiği -ya da tam tersi yapılamadığı- medya içeriğinde şiddet estetize edilmelidir. Edilmelidir ki, bireyin şiddete olan açlı̆̆ sürsün ve böylelikle medya içeriği tüketilmeye devam etsin; birey kendi iç dünyasının yansımalarına ayna tutan medyaya ve medyayı güdümünde tutanlara sonsuz biat etsin ${ }^{18}$.

Bu noktada estetize edilen şiddet, aynı zamanda gücün, iktidarın, cüretkarlığın, anarşinin, kaosun, iğrençliğin, pornografinin ve korkunun estetize edilmiş hali olmaktadır. "Bir zamanlar Homeros'ta, Olimpos Dă̆ğndaki tanrlarn gözzünde bir tür sergi malzemesi olan insanlik, șimdi kendi kendisi için bir sergi malzemesi olup

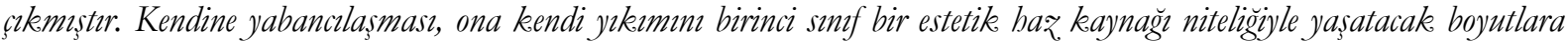
varmustur" (Benjamin, 2002, s. 79).

\section{Sonuç Yerine}

Şiddet, insanlığın ortaya çıkışından itibaren hayatın içerisinde şu ya da bu şekilde varlı̆̆ını sürdüregelen bir olgudur. Bununla birlikte, şiddetin en görünür hale geldiği dönem, içinde yaşadığımız dijital çağ olmuştur denilebilir. Zira bugün birey etrafi iletişim teknolojileri çevrilmiş durumdadır ve her bir medya türünde şiddetin farklı formlarıyla, farklı tasavvurlarıyla ve farklı tezahürleriyle karşılaşmaktadır. "Bu bir maruz kalış mıdır, yoksa talebe yönelik oluşturulan arz mıdır?" sorusuna verilecek cevap ise bizi bir madalyon metaforu kullanmaya itmektedir. Bu madalyonun bir yüzünde şiddet sahnelerini oluşturma, yayma ve aktarma vardır. Şiddet sahneleri yüzlerce, hatta binlerce yıldır kimi zaman dini kurumlara itaat edilmesini sağlamak, kimi zaman siyasi iktidarın bir güç gösterisi, kimi zaman bir ceza ve denetim, kimi zaman ise toplum içerisindeki gerginliği sağaltma amacıyla kullanılmıştır. Bir yandan seyirlik hale getirilen şiddet uygulamaları, örneğin kalabalık bir seyirci kitlesinin gözleri önünde vuku bulan kurban törenleri, idam cezaları, gladyatör / şövalye dövüşleri, vb. olaylar, seyredende korku, coşku, duygu boşalımı gibi sonuçlar elde etme amaçlı kullanılırken; diğer yandan aynı veya benzer amaçlarla dini metinlerde, sanat eserlerinde, gerçeğe dayalı ya da kurgusal içerikli kitaplarda ve görsel - işitsel metinlerde hep ve sürekli yer alagelmiştir. Bugün ağırlıklı olarak -görsel / işitsel medya içeriğinde- karşımıza çıkan şiddet; ki bu noktada sözü edilen şiddetin beden bütünlüğünün bozulmasıyla sonuçlanan şiddet olduğunu tekrar vurgulamakta yarar bulunmaktadır; giderek artan biçimde yer almakta, gündelik hayata ve dünyaya dair algılarımızı da Gerbner'in Kültürel Göstergeler Yaklaşımı'ndan yola çıkarak şüphesiz- şekillendirmektedir. Bu, kimi zaman cinsel içerikli bir şiddettir, kimi zaman yoğun bir öfkenin eyleme dökülmesidir. Kimi zaman bireysel bir suçun yansıması, kimi zaman ise kitlesel bir kıyımdır. Bazen gerçeklik (haber bültenleri, vb.), bazen kurgusallık (filmler, diziler, romanlar, dijital oyunlar, vb.), bazen de gerçek olaylardan beslenen kurgusallıktır (reality showlar, biyografi nitelikli hemen her türden medya içeriği). Hangi formuyla karşımıza çıkarsa çısın açıça görülmekte olan, şiddetin seyirlik bir haz nesnesi olarak sunumudur. İletişim teknolojilerindeki gelişmeler arttıkça da şiddet içerikli imgeler daha da görünür hale gelmektedir.

Madalyonun diğer yüzünü oluşturan ise izlerkitlenin şiddet içerikli görüntülere ve anlatılara olan ilgisidir. İzlerkitle sadece medya içeriğine maruz kalmamakta, kendi ilgisi, ihtiyaçları ya da istekleri doğrultusunda şiddeti aramaktadır. Öyle sıradan şiddet içerikleri de değildir artık aranan, hep daha fazla tedirginlik ve şaşkınlık yaratacak, hep daha fazla gerçekliği üzerine düşündürecek, insanlığın ne hale geldiğiyle ilgili sorgulama yapma sayısını arttıracak içerikler aranmaktadır. Artık sadece kan yetmemektedir mesela, paylaşılan içeriklerin ardında derinlemesine bir şiddet hikayesi olmalıdır; "cinayet" kavramı başlı başına yetmemektedir, yanına "hunharca işlenen" söylemini almalıdır; öldürülen kişiler kesinlikle olmalıdır ama bu yetmemektedir, elbette "maktul / maktule tecavüze uğramış" da olmalıdır; daha sonrasında o ölen

\footnotetext{
17 Fantazmagori: Aldatıcı görüntü. Benjamin bu kavramı, kapitalist toplumların büründüğü pırıltı olarak nitelendirmektedir. Fantazmagoriler, "yüzyllın sihirli görüntüleridir”; fantazmagoriler, bu yüzyllın toplumunun "idealleridir”; sözü edilen toplum, bu ideallerin yardımıyla "gerek toplumsal ürünün eksikliklerini, gerekse toplumsal üretim düzeninin aksayan yanlarını hem gidermeye, hem de yüceltmeye" çalışmıştır (Benjamin, 2002, s. 28). Şiddetin estetize edilerek sunulması kapsamında bakıldığında da -medya kurumlarının ticari yapılanmalar olmaları dolayısıyla- bu işlev aynıyla ele alınabilir niteliktedir.

${ }^{18}$ Bu konu ile ilgili olarak Noam Chomsky’nin kitaplarına ve Immediast Grubu'nun söylemlerine bakılabilir.
} 
kişilerin otopsi masasında bedenlerine olanlar gibi -mümkünse bunun da görüntülerine ulaşılmalıdırhayatlarına da otopsi yapılmalı, içi açılmalı, tüm detaylar tartılmalı, ölçülmeli, biçilmeli ve tartışılmalıdır. Basitçe, hayli popüler bir video paylaşım kanalı olan Youtube'da "seri katiller" ya da "serial killers" anahtar kavramlarıyla yapılacak arama dahi bunun bir göstergesidir aslında. Sadece bu kavramlar aratıldığında dahi, milyonlarca izlenme sayısına sahip çok sayıda video ekranda belirmektedir. İnsanlar bu videoları izlemekte, sonrasında yorum da yapmaktadır. Örneğin tüm zamanların en korkunç seri katillerinden biri olan ve bilindiği kadarıyla 17 kişinin ölümünden sorumlu Jeffrey Dahmer ile ilgili 43 dakikalık bir video 5 milyonun üzerinde kişi tarafindan izlenmiştir. Videonun altında yer alan yorumlara bakıldığında, çoğunlukla Dahmer ve / veya kurbanlarla ve hatta bu cinayetlerde söz konusu olan eylemlerle alay edilmekte, en hafif deyimle bu konu üzerinden mizahi(!) söylemler üretilmektedir. Öte yandan Google'da aratıldığında yüzlerce sayfa ekrana gelmekte; Dahmer'ın hayatı, işlediği cinayetler, kurbanların özellikleri ve hayatları gibi pek çok konuda son derece detaylı bilgiler yer almaktadır. Bu öylesine ilgi çekici bir konudur ki, "Arkadaşım Dahmer" adı ile yayınlanan kitap sonrasında film olarak gösterime girmiştir. Ancak, yine internet üzerinden yapılan yorumlara bakıldığında okuyucu da izleyici de aradığını bulamamış görünmektedir. Zira film Dahmer'ın en cani eylemlerinin olduğu seri katillik yıllarını değil, lisedeki genç Dahmer'ı ve O'nu sonrasında olduğu kişi yapan olaylar dizisini ele almaktadır. Diğger bir deyişle işlenen asıl cinayetler kitap ya da filmde olmadığından izlerkitlede hayal kırıklı̆̆ı oluşmuştur. Bütünüyle kurgusal medya içeriği bağlamında da izlenme oranı en yüksek diziler içerisinde bu türden içeriğe sahip olanların çoğunlukta olduğu görülmektedir. Sadece kötülerin hayatına son veren ve bunu inanılmaz bir vahşet içerisinde yapmasına rağmen seyircinin sempatisini kazanan seri katil hikayesi Dexter (ki çizgi romandan uyarlanmıştır), tarihin sayfalarından gelen bir kahraman olarak bir gladyatörün kanlı özgürlük mücadelesini aktaran Spartacus, doğaüstü varlıklar ile hikayelerin işlendiği ve özellikle gençlerin ilgisini çeken The Vampire Diaries, True Blood ve hatta The Walking Dead gibi diziler bu noktada örnek gösterilebilir. Bu noktada ülkemizden de bazı örnekler vermek mümkündür. Önde gelen ulusal kanalların pek çoğunda, işlenen şiddet içerikli suçların özellikle de cinayetlerin farklı uzmanların da katılımıyla tartışıldığı programlar oldukça yüksek izlenme oranlarına ve sadık birer izleyici kitlesine sahiptir. ATV'de Müge Anlı, TV8'de ise Serap Paköz tarafindan sunulan programlar bu bağlamda en çarpıcı örnekler olarak ifade edilebilir. Söz konusu programlara olan yoğun ilgi, sosyal medya hesaplarındaki izleyici yorumlarıyla da netleşmektedir. Asıl amacı adalet ve güvenliği sağlamaya çalışan resmi kurumlara medyanın gücünü kullanarak yardımc1 olmaya çalışmak olan bu programların yarattı̆̆ı etki, kimi (hatta çoğu) zaman pornografik bir hal almaktadır. Bu programlarda elbette açıcça öldürülen ve/veya acı çeken bedenler gösterilmemektedir. Ancak olayların derinlemesine anlatımı, suçun işlenme biçimi üzerinde konuşulan olasılıklar, yapılan çıkarımlar izlerkitlenin hayal gücünü tetikler görünmektedir. En azından, bu programların sosyal medya hesaplarındaki iletilere yapılan yorumlar bu yönde bir izlenim oluşturmaktadır. Yanı sıra gazete haberleri ve kösse yazıları da -ki çoğu zaman fotoğraf kullanmamalarına rağmen- pornografik bir içeriğe sahip olabilmektedir. Münevver Karabulut, Özgecan Arslan gibi toplumda infiale yol açan olayların detaylarının sunumu bu bağlamda değerlendirilebilmektedir. Son olarak örnek verilebilecek bir diğer alan dijital oyunlardır. Çevrimiçi, video ya da konsol oyunları içerisinde, oynanma oranı en yüksek oyunlar genelde şiddet içerikli olanlardır. League of Legends, WOW, Star Wars, Tomb Raider ve daha nice şiddet içerikli oyun, sektörün önde gelen örneklerindendir. Bu noktada vurgulanması gereken bir diğer konu ise şiddetin pornografik olduğu kadar estetize edilerek de sunuluyor olmasıdır. Özellikle kurgusal içerikte, her ne kadar şiddet eylemleri tüm çıplaklığıyla gösterilse dahi estetik bir formda da izlerkitlenin karşısına çıkmaktadır. Bedensel bütünlüğe verilen fiziksel zarar (kan damlalarının sıçrayışından, ölü bedenlerin güzelliklerine değin) son derece estetik bir biçimde sunulmaktadır.

Bu durumu ortaya çıkaran nedenlerin başında ise muhtemeldir ki -çalışmanın giriş kısmında verilen Marina Abramovic’in gösterisine insanların verdiği tepkiden yola çıkarak bu türden bir saptama yapmak mümkündür- bireylerin şiddeti gerçeklikte deneyimlemelerinin onlarda yaratacağı olası travmatik etkilerden bir tür kaçı̧̧ olarak şiddeti fantazmagorik ortamlarda deneyimlemeye yönelmeleridir. Birey, şiddet içeriğine karşın bir açlık hissetmektedir. Ancak bu şiddeti gerçek hayatta deneyimleme konusunda isteksizdir. Oysa fantazmagorik bir biçimde deneyimlenen şiddet, istendiği an sona erdirilebilmekte, gerçek hayatta etkisiz kalmakta, daha da önemlisi bireyi gerçek şiddet eylemlerinin kurgusaldaki kadar estetik görünmeyen sonuçlarından da korumaktadır.

Bu türden savların kesinlik kazanması elbette hem medya içeriğine dayalı detaylı analizleri, hem de izlerkitle üzerinde yürütülecek etki araştırmalarını gerektirmektedir. Ancak daha önce de vurgulandığı üzere, bu çalışmada şimdiye değin aktarılanlar çerçevesinde kuramsal bir bağlam oluşturulmaya çalışılmaktadır. Bu çalışma bütünüyle, bu kapsamda yapılacak araştırma ve çözümlemelere kuramsal bir 
temel oluşturulma çabası içerisindedir. Ancak görünen odur ki, şiddetin medya içeriğinde pornografik ve estetik sunumu ile izlerkitlenin şiddet içeriğini arayışı derinlemesine incelenmesi gereken çalsşma alanlarıdır.

\section{Etik Beyan}

"Medya İçeriğinde Şiddetin Sunumu Üzerine Argümantatif Bir Çalısma" başlıklı çalışmanın yazım sürecinde bilimsel, etik ve alıntı kurallarına uyulmuş; toplanan veriler üzerinde herhangi bir tahrifat yapılmamış ve bu çalışma herhangi başka bir akademik yayın ortamına değerlendirme için gönderilmemiştir.

\section{Kaynakça}

Akıner, N. (2014). Bir modern zamanlar silahı olarak medya: kaddafi'nin lincinin satır arasını okumak, esad'ı anlamak. Akademik Sosyal Arasstrmalar Dergisi, 2(1), 1-19. Erişim adresi: http://www.asosjournal.com/Maka leler/1988250809_71-nurdan\%20ak\%c4\%b1ner.pdf

Aronson, E., vd. (2010). Sosyal psikoloji (Çev: O. Gündüz). İstanbul: Kaknüs Yayınları.

Arslan, C., vd. (2010). Ergenlerde saldırganlı ve kişilerarası problem çözmenin incelenmesi. İlköğretim Online, 9(1), 379-388. Erişim adresi: http://www. http://ilkogretim-online.org.tr

Aydın, H. (2000). Öğrenme ve öğretme kuramlarının eğitim iletişimine katkısı. Kurgu Dergisi, 17, 183-197. doi: 10.14686 /buefad.528904

Baudrillard, J. (2001). Simgesel değğs tokus ve ölüm (Çev: O. Adanır). İstanbul: Boğaziçi Üniversitesi Yayınevi.

Baudrillard, J. (2004). Tam ekran (Çev: B. Gülmez). İstanbul: YKY.

Benjamin, W. (2002). Pasajlar (Çev: A. Cemal). İstanbul: YKY.

Benjamin, W. (2007). Illuminations, essays and reflections (Çev. H. Zohn). New York: Schocken Books.

Bloch, M. (1983). Feodal toplum (Çev: M. A. Kilıçbay). Ankara: Savaş Yayınları.

Boyle, K. (2005). Media and violence. London: Sage Publications.

Buda, C. (2017). The concept of the aesthetics. RAIS Journal for Social Sciences, 1(1), 44-51. Erişim adresi: http://journal.rais.education/index.php/raiss/issue/view/1

Cho, D. K. (2006). Thanatos and Civilization: Lacan, marcuse, and the death drive. Policy Futures in Education, 4(1), 1830. doi: 10.2304\%2Fpfie.2006.4.1.18

Erdem, M.N. (2014). Violence and pornographic violence as a mass entertainment medium: A study on Spartacus series. İçinde G. Öztürk (Ed.), Handbook of Research on the Impact of Culture and Society on the Entertainment Industry. (ss. 278-294) ABD: IGI Global.

Erdoğan, İ. ve Alemdar, K. (2005). Öteki kuram: Kitle iletişim kuram ve araștrmalarnm taribsel ve eleștirel bir değerlendirmesi. Ankara: Erk Yayınlar1.

Ertürk, N. (2015). A. G. Baumgarten'da duyusal bilginin bilimi olarak estetik. Ulakbilge, 4(7), 117-129. doi: 10.7816/ulakbilge-04-07-07

Freud, S. (2012). Totem and tabu (Çev: K. Sipal). İstanbul: Say Yayınları.

Fromm, E. (1993). İnsandaki yıkııchğgn kökenleri (Çev. Ş. Alpagut). İstanbul: Payel Yayınları.

Gençtanırım, D. ve Voltan Acar, N. (2007). Akılcı-duygusal davranışçı yaklaşım ve Sezen Aksu şarkıları. Eğitim ve Bilim Dergisi, $32(143), \quad$ 27-40. Erişim adresi: http://egitimvebilim.ted.org.tr/index.php $/ \mathrm{EB} /$ article/viewFile/827/180

Girard, R. (2003). Şiddet ve kutsal (Çev: N. Alpay). İstanbul: Alfa Yayınları.

Gottfried Herder, J. (2006). Selected writings on aesthetics. ABD: Princeton University Press.

Gök, M. (2009). Aile içi şiddet ve öfke ifade tarzlar arasindaki iliskinin incelenmesi (Yüksek Lisans Tezi). Çukurova Üniversitesi Sosyal Bilimler Enstitüsü, Adana.

Graves, R. (2010). Yunan mitteri (Çev: U. Akpur). İstanbul: Say Yayınları.

Gümüş, S. (2011). Saldrrganllk ile aile içi şiddet arasindaki ilişkinin incelenmesi (Yüksek Lisans Tezi). İstanbul Arel Üniversitesi Sosyal Bilimler Enstitüsü, İstanbul.

Jung, C.G. (2001). Four Archetypes. Londra: Routledge.

Kahn, S. (2016). Eros and thanatos: A psychoanalytic examination of death in the context of working life. Management Forum, 4(3), 29-40. doi: 10.15611/mf.2016.3.05

Kim, N. (2006). A history of design theory in art education. Journal of Aesthetic Education, 40(2), 12-28. doi: $10.1353 /$ jae. 2006.0015

Kiraz, S. (2015). Hayvanda ve insanda saldirganlık üzerine psikolojik ve felsefi bir inceleme. FLSF (Felsefe ve Sosyal Bilimler Dergisi), 19, 119-136. Erişim adresi: https://dergipark.org.tr/tr/pub/flsf/issue/48624/617782

Leder, H. vd. (2004). A model of aesthetic appreciation and aesthetic judgments. British Journal of Psychology, 95, 489508. doi: $10.1348 / 0007126042369811$

Mutlu, E. (2004). Illetişim sözlïğ̈. Ankara: Bilim ve Sanat Yayınları.

Krahé, B. vd. (2011). Desensitization to media violence: links with habitual media violence exposure, aggressive cognitions, and aggressive behavior. Journal of Personality and Social Psychology, 100(4), 630-646. doi: $10.1037 / \mathrm{a} 0021711$

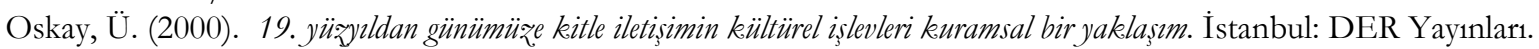


Özaşçılar, M. (2016). Şiddet davranışının nedenlerini açıklamada biyolojik temelli kuramların rolü. Türk Psikoloji Yąılar Dergisi, 19, 16-28. Erişim adresi: https://www.psikolog.org.tr/tr/yayinlar/dergiler/ 1031828/tpy1301996120160000m000044.pdf

Özerkmen, N. (2012). Toplumsal bir olgu olarak şiddet. Akademik Bakıs Dergisi, 28, 1-19. Erişim adresi: http://www.acarindex.com/akademik-bakis-uluslararasi-hakemli-sosyal-bilimler-dergisi/toplumsal-bir-olguolarak-siddet-1680\#.Xly5xagzbIU

Özkan, S. (2017). Gerbner'in kültürel göstergeler kuramı bağlamında televizyon haber içeriklerine ilişkin bir araştırma. Abant Kültürel Araștrrmalar Dergisi (AKAR), 2(4), 129-141. Erişim adresi: https://dergipark.org.tr/tr/pub/akader/issue/31877/350402

Polat, O. (2016). Şiddet. Marmara Üniversitesi Hukuk Fakültesi Hukuk. Araștırmalar Dergisi, 22(1), 15- 34. Erişim adresi: https://dergipark.org.tr/tr/pub/maruhad/issue/27591/290653

Sargın, A. (2007). Pornografi ve kadına yönelik şiddet. ODTÜ Sosyoloji Günleri Kapsamında Sunum. Erişim adresi: https://bianet.org/kadin/medya/95989-pornografi-siddet-ve-kapitali zm-3

Sayın, Z. (2003). Imgenin pornografisi. İstanbul: Metis Yayınc1lı.

Sontag, S. (2004). Başkalarmm acısına bakmak (Çev: O. Akınhay). İstanbul: Agora Kitaplığı.

Şimşek, İ. (2014). Antikçă̆dan Alman idealizmine; estetik bir değer olarak güzellik. Atatürk Üniversitesi İlabiyat Fakültesi Dergisi, 41, 329-345. Erişim adresi: https://dergipark.org.tr/tr/pub/atauniilah/issue/2758/36825

Tekel, A. (2015). Estetik yarg1 ve estetik yarg1y1 etkileyen faktörler. Sanat ve Tasarm Dergisi, 16, 149-157. doi: $10.18603 /$ std.64941

Trend, D. (2007). Medyada şiddet efsanesi (Çev: G. Bostanc1). İstanbul: YKY Yayınları.

Tunalı, İ. (1998). Estetik. İstanbul: Remzi Kitabevi.

Türkoğlu, N. (2007). Toplumsal iletişim. İstanbul: Kalemus Yayınları.

Uzunaslan, A. (2005). Antik Roma'da gladyatör oyunları. Süleyman Demirel Üniversitesi Fen-Edebiyat Fakültesi Sosyal Bilimler Dergisi, 12, 15-58.

Ünsal, A. (1996). Genişletilmiş bir şiddet tipolojisi. Cogito: Siddet, 6-7, 29-36.

Wiedemann, T. (2002). Emperors and gladiators. ABD: Routledge Publications.

Weaver, J. W., Wilson, B. J. (2009). The role of graphic and sanitized violence in the enjoyment of television dramas. Human Communication Research, 35, 442-463. doi: 10.1111/j.1468-2958.2009.01358.x

Wilkinson, P. (2010). Efsaneler ve mitler (Çev: E. Lakşe). İstanbul: Alfa Yayınları.

Williams, R. (1993). Kültür (Çev: S. Aydın). Ankara: İmge Kitabevi.

Wisdom, S., McBride, A. (2001). Gladiators 100 BC - AD 200. UK: Osprey Publishing.

Xenakis, I., Arnellos, A. (2014). Aesthetic Perception and Its Minimal Content: A Naturalistic Perspective. Journal of Frontiers in Psychology, 19, 1-15. doi: 10.3389/fpsyg.2014.01038

Yavuzer, N. (2013). İnsanın saldırgan ve yıkıcı doğasını anlamak. İstanbul Ticaret Üniversitesi Sosyal Bilimleri Dergisi, 12(23), 43-57. Erişim adresi: https://ticaret.edu.tr/uploads/yayin/sosyal23/3_43_57_Sosyal_23.pdf

Yüksel, M. (2004). Modern kültürde hukuk ve ahlak. RTÜK (Radyo ve Televizyon Üst Kurulu) toplantısinda sunulan çalısma. İstanbul, Türkiye. Erişm adresi: http://www.etik.gov.tr/wp-content/uploads/2019/03/mehmetyukselmodernlesmebaglamindahukukveetik.pdf

Web 1: https://www.youtube.com/watch?v=kijKz3JzoD4

Web 2: http://www.tdk.gov.tr/; Erişim Tarihi: 04.02.2018

Web 3: https://en.oxforddictionaries.com/definition/violence; Erişim Tarihi: 04.02.2018

\section{EXTENDED ABSTRACT}

The phenomenon of violence in society and mass media is a popular discussion topic for the academics who studies in communication science field. On the other hand, the existence of discussions on violence is not old as the existence of violence. In other words, the pages of history is full with the documents which has demonstrated of the violence behaviors of human being that have done to other people, societies or any other species. These kind of behaviours sometimes have become indicators of proof of power, political power or an inspection mechanism, and sometimes creating substitution of real emotions or a medium of entertainment, etc. The violence always has showed itself in daily life from ancient times to today's world. But, it can be said that, the world of 21 st century has become the age of the demonstration of violence. Developments in communication technologies have led to the spread of a large number of fictional or real violent media content. This unconcerned spreading of violence content has brought about the accusation of media by many scientist. And especially in critical studies of communication field, the unconcerned attitudes of media institutions and publishing / broadcasting politics of violence content as a result of these attitudes have become a focus point. On the other hand, there are many studies and researches about violence that focusing on the dimension of audience such as Cultural Studies, Reception Studies and Uses and Gratification Approach. In other words, the world of Communication Sciences seems like separated to two about the violence content and its reflections in society: Critical Theoricians and Perception Theoricians. Actually, the represents both of these theories have right justifications about their arguments. On the one hand, media institutions give time and place in 
their many different channels to publishing / broadcasting of violence content without hesitation and without thinking about public interest, with only worrying about ratings and circulations, -and even, this kind of behavior can be evaluated even as a method of political inspection mechanism to keep away the audiences from the real agenda. On the other hand, the audiences who have the ability to choose of many other contents from the wide media pool, have used their choices for the violence content. In other words, the media commit violence in almost all kinds of content, particularly due to a track-record and / or circulation concern resulting from commercially profit-making purposes; and the viewer does not turn his / her gaze from this kind of content and approaches it with interest. At this point, it can be mentioned about two kinds of representation of violence in the both traditional and digital media: pornography of violence and aesthetics of violence. The pornography of violence includes the visualisation of the body that as a victim of violence and the exposure of the act of violence and its background; besides the pleasure of audiences in the face of this exposure. The pornographic presentation or reception of violence has come up in different ways since ancient times and continues to emerge. The fine line that separates the present from the past is primarily the magnitude of the mass achieved and secondly the transition from reality to fictionality. But humankind always sees the violence of his own kind with a sense of pleasure mixed with interest and disgust. In other words, the audiences can neither prevent themselves from watching violent content, nor can they avoid critical seeing. The subject of aesthetic of violence can be evaluated from this perspective, too. Despite the fact that the concept of "aesthetics" is a field of science, which includes the evaluating of beauty and art within the universal codes; it is also used for everything which has accepted as beatiful and give pleasure to people. This is also the case in the presentation of violence in the media. As discussed in the scope of the study, visuals that convey the disruption of the integrity of the human body in the media or the narratives created in this context are presented by aesthetizing. One of the main reasons for such an approach seems to lie in the audience's inclination to the content of violence. Human beings are very interested in witnessing violence against their own species, -even with a Freudian point of view, they instigates their instinctive tendencies with this testimony. However, there are also some consequences of this testimony. First of all, the human being is not successful about to face with the consequences of violence that he / she resorted himself / herself; or the violence among the human beings. The individual avoids the act of violence because of sometimes to avoid this feeling, and sometimes to avoid punishment legally; or with other reasons. Inspite the fact that, the media violence can trigger the acts of violence in real life, the audience usually settled with the act of watching. Because, audiences know the media violence is fictional, and they don't have to worry about the real consequences. Aestheticization of violence makes easy to watch violence content, though. In this context, in this study, firstly, the studies on why and how violence is manifested in human are discussed. Then, a perspective is based on the pornographic presentation and esthetization of violence. The aim of this study is not to make an impact study on the mass in this context or to analyze the pornographic presentation or esthetization of violence. In addition, a theoretical basis for research and analysis is to be established. 